\title{
UTILIZAÇÃO DO TANQUE DE EVAPORAÇÃO CLASSE "A" PARA O CONTROLE DA IRRIGAÇÃO POR GOTEJAMENTO EM SOQUEIRA DE CANA-DE-AÇÚCAR ( $\delta_{\text {accharum spp.) }}$
}

MIGUEL VISCAÍNO CARRETERO

Engenheiro Agrônomo

Orientador: Prof. Dr. RUBENS SCARDUA

Dissertação apresentada à Escola Superior de Agricultura "Luiz de Queiroz", da Universidade de São Paulo, para obtenção do título de Mestre em Agronomia. Área de Concentração: Solos $\theta$ Nutrição de Plantas.

PIRACICABA

Estado de São Paulo - Brasil

Outubro, 1982 
Ao

Sr. FRANCISCO VISCAINO SANCHES, meu pai,

agricultor dedicado, cuja honestidade e virtude

nos serviu de exemplo.

"In memorion"

Sra. DOLORES, minha mãe

MARIA APARECIDA, minha esposa

MARGARETH APARECIDA, minha filha

que mitigam minhas horas de cansaço

$e$ alentam meus instantes de incorteza.

DEDICO. 
"E preferivel arriscar coisas grandiosas, alcansar triunfos e glörias, mesmo expondo-se à derrota, do que formar fiza com os pobres de espirito que não gozan muito, nem sofrem muito, porque vivem na penumbra obscura e cinzenta dos que não conhecem nem a vitöria, nem a derrota".

"Não hã sucesso onde não existe a possibizidade do fracasso". .

P. Cbandier 
A Deus por ter-me dado forças para ir até o fim.

A Todos que, direta ou indiretamente, contribuiram para a realização deste trabalho. 
vi.

\section{INDICE}

RESUMO $\ldots \ldots \ldots \ldots \ldots \ldots \ldots \ldots \ldots \ldots \ldots \ldots \ldots \ldots \ldots \ldots \ldots \ldots \ldots \ldots \ldots \ldots \ldots$

SUMMARY $\ldots \ldots \ldots \ldots \ldots \ldots \ldots \ldots \ldots \ldots \ldots \ldots \ldots \ldots \ldots \ldots \ldots \ldots$

1. INTRODUÇAO $\ldots \ldots \ldots \ldots \ldots \ldots \ldots \ldots \ldots \ldots \ldots \ldots \ldots \ldots \ldots$

2. REVISAOO DE LITERATURA ................... 4

2.1. Irrigação por gotejamento $\ldots \ldots \ldots \ldots \ldots \ldots \ldots \ldots$

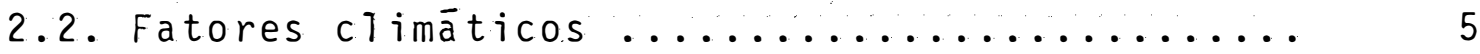

2.2.1. Evapotranspiração/Evaporação ......... 7

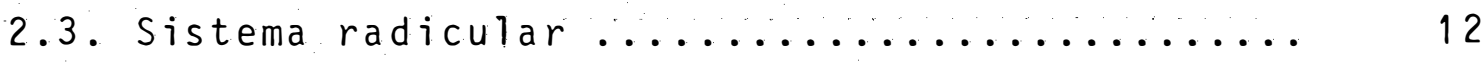

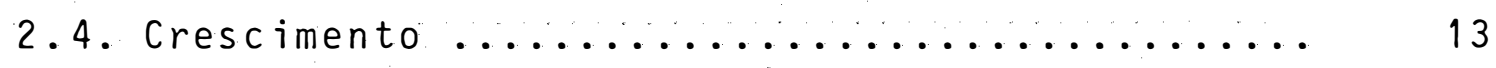

2.5. Necessidade de irrigacão, relacionada com a produção ........................ 17

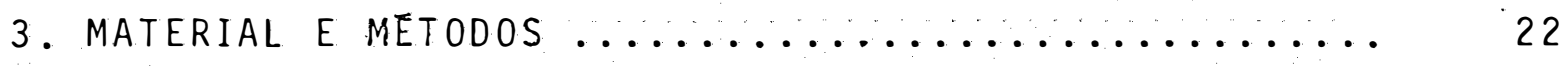

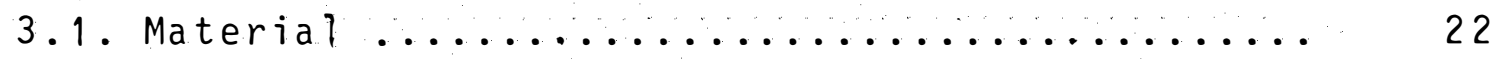

3.1.1. Descricão geral da àrea de estudo ..... 22

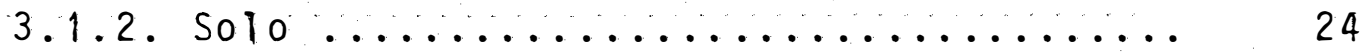

3.1.2.1. Caracteristicas físicas e quí-

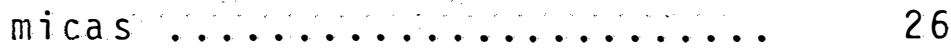

3.1.3. Variedade de cana-de-açūcar ......... 30

3.1.4. Equipamento de irrigação ........... 31

3.1 .5 . Dados meteorológicos ............. 31

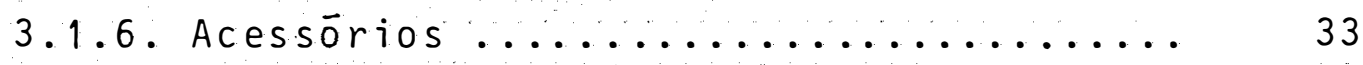

3.2 . Métodos $\ldots \ldots \ldots \ldots \ldots \ldots \ldots \ldots \ldots \ldots \ldots \ldots \ldots \ldots \ldots \ldots \ldots \ldots$

3.2 .1 Del ineamento experimental ......... 33

3.2.2. Instalação do experimento .......... 34

3.2.3. Condução da irrigação - cana soca e res

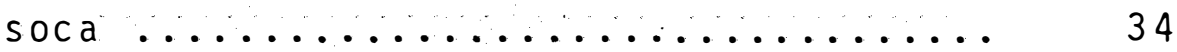

3.2.4. Adubação da soca e ressoca .......... 38

3.2 .5 . Anā 1 ise dos dados $\ldots \ldots \ldots \ldots \ldots \ldots \ldots . \ldots \ldots$

3.2 .5 .1 . Crescimento da cana ........ 38 
3.2.5.2. Relações entre o desenvolvimen to vegetativo da soca e ressoca e condições climáticas ....

3.2.5.3. Produtividade e número de col-

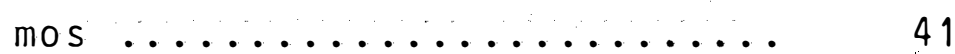

3.2.5.4. Anālise estatistica ......... 41

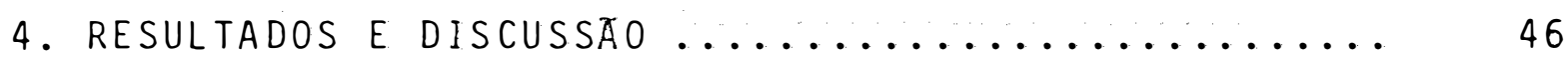

4.1. Volume de àgua a plicado ................ 46

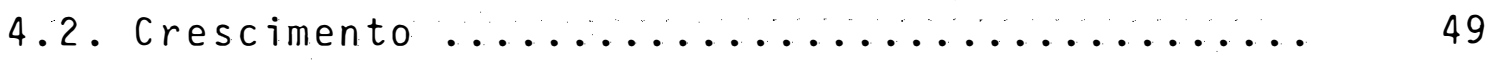

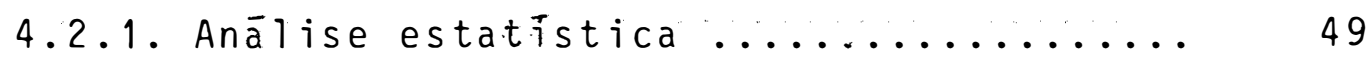

4.2.2. Relações entre desenvolvimento vegetati vo da soca e ressoca e condições climá-

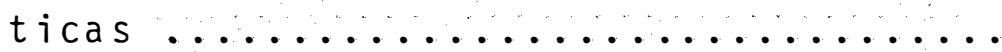

4.2.2.1. Caracterização do desenvolvi mento vegetativo e da função

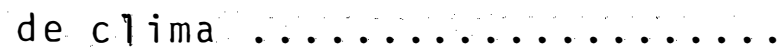

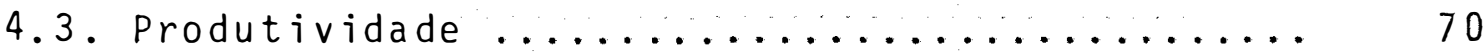

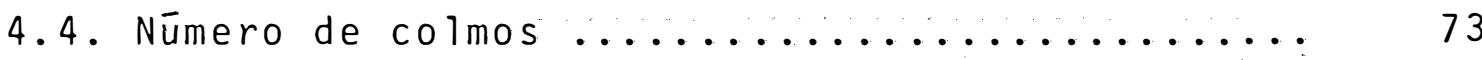

4.5. Dotação de àgua e produtividade ........... 73

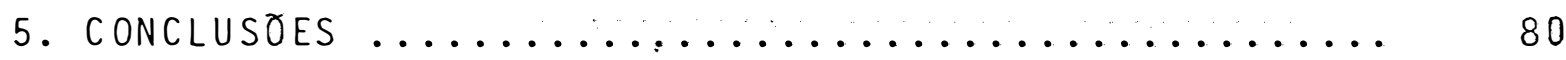

6. LITERATURA CITADA $\ldots \ldots \ldots \ldots \ldots \ldots \ldots \ldots \ldots \ldots \ldots \ldots \ldots \ldots \ldots$ 
1 Correlações ER/Eo (CRUCIANI, 1972) ........

3 Dados meteorológicos durante o perīodo de irri

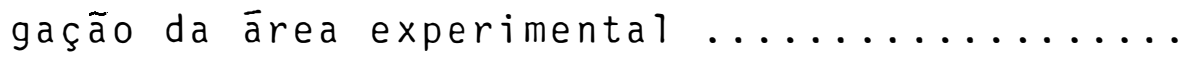

4 Características gerais da Terra Roxa Estrutura

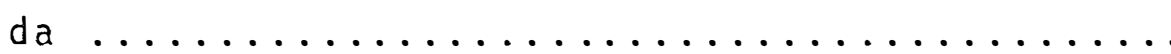

5 Características físicas e químicas do solo da ārea experimental do Departamento de Engenha-

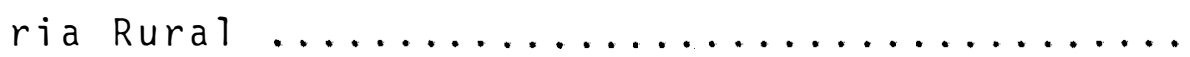

6 Comparação entre a POL das variedades CB 41-76

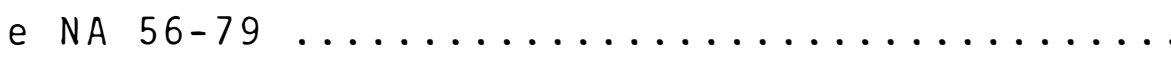

7 Dotação de āgua para os tratamentos A, B, C, D, considerando-se as precipitações e evaporações do tanque Classe A a cumuladas mensalmente nope ríodo de agosto de 1977 a 5 de julho de 1978 ,

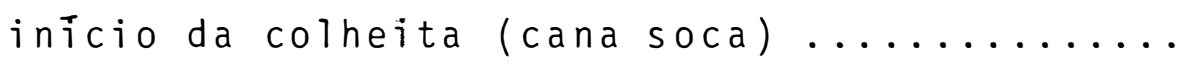

8 Dotação de àgua para os tratamentos A, B, C e D, considerando-se a precipitação pluviométrica e evaporação do tanque Classe A acumulados mensalmente no periodo agosto 78 a abril 79. In $\bar{i}-$ cio da colheita (cana ressoca - 28/08/79) .... 
10 Dados de crescimento da cana em cm - cana res

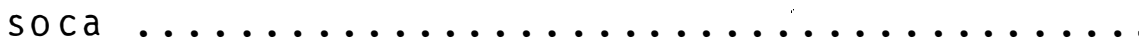

11 Análise de variância dos dados de crescimento do colmo, em esquema "Split-Plot" - Cana soca.

12 Anālise de variància dos dados de crescimento do colmo em esquema "Split-Plot" - Cana resso-

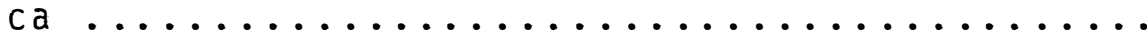

13 Desenvolvimento vegetativo da cana soca e

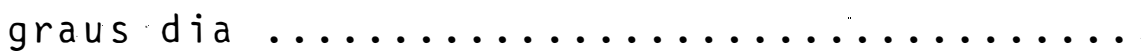

14 Desenvolvimento vegetativo da cana ressoca e

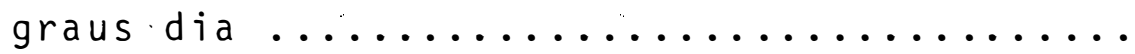

15 Equações de regressão entre crescimento $(\Delta H)$ e graus dia acumulados, no periodo. Cana so-

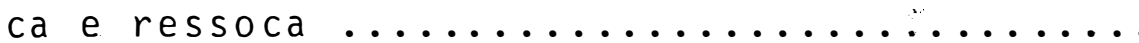

16 Número e crescimento de colmos e produção de cana e açūcar em relação as dotações de àgua.. 71

17 Dados de produtividade e nūmero de colmos ...

18 Anālise de variāncia dos dados de produtivida de de cana e médias de tratamentos. Cana so-

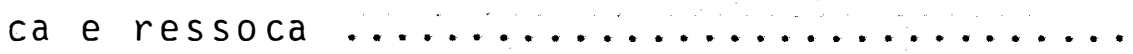

19 Anālise de variāncia dos dados de nūmero de colmos e médias de tratamentos. Cana soca e

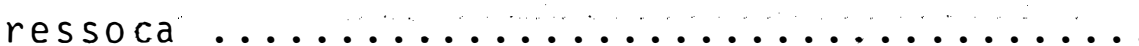




\section{LISTA DE FIGURAS}

Figura

Pàgina

1 Localização do municĩpio de Piracicaba no Estä

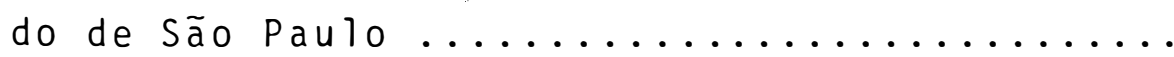

2 Mapa esquemātico mostrando a localização da Terra Roxa Estruturada no Estado de São Paulo segundo a Comissão de Solos do Serv. Nac. de

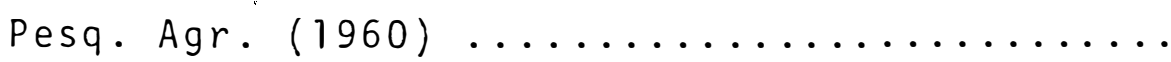

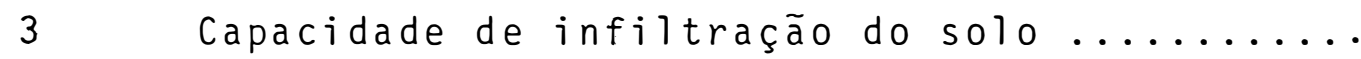

4 Curva característica da āgua do solo ........

5 Equipamento de irrigação por gotejamento usado

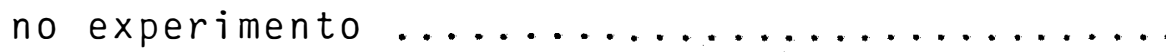

6 Campo experimental e detalhe da parcela expe-

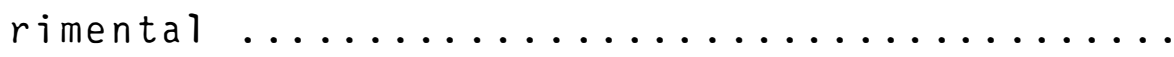

7 Curvas de crescimento da cana soca ...........

8 Curvas de crescimento da cana ressoca ........

9 Curva de Graus Dia x Crescimento do tratamen-

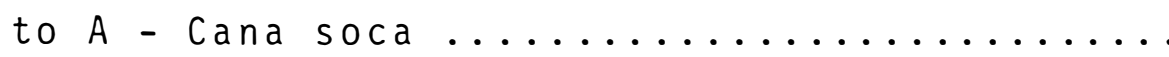

10 Curva de Graus Dia x Crescimento do tratamen-

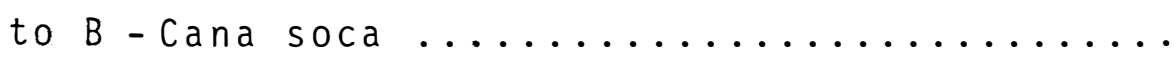

11 Curva de Graus Dia x Crescimento do tratamen-

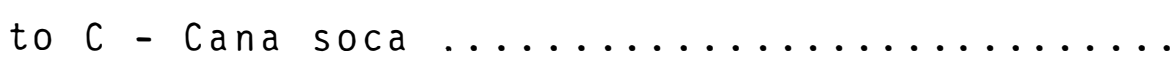


12 Curva de Graus Dia x Crescimento do tratamen-

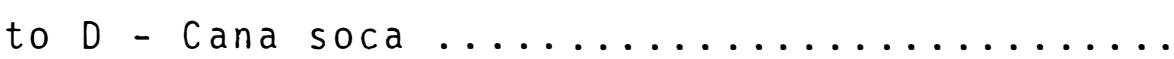

13 Curva de Graus Dia x Crescimento do tratamen-

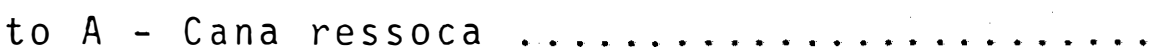

14 Curva de Graus Dia x Crescimento do tratamen-

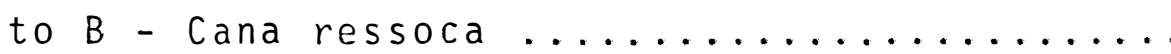

15 Curva de Graus Dia x Crescimento do tratamento $c$ - Cana ressoca .................... 68

16 Curva de Graus Dia x Crescimento do tratamen-

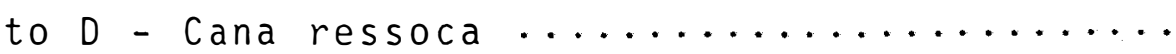

17 Precipitações pluviométricas - Posto DER -

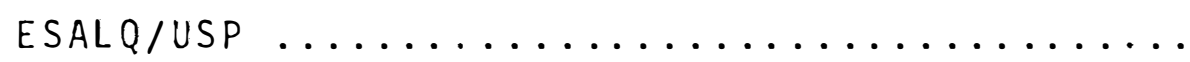


UTILIZACAO DO TANQUE DE EVAPORAÇAO CLASSE "A" PARA 0 CONTROLE DA IRRIGACAO POR GOTEJAMENTO EM SOQUEIRA DE CANA-DE-ACUCAR (Saccharum spp.)

\author{
Autor: Miguel Viscaino Carretero \\ Orientador: Dr. Rubens Scardua
}

RESUMO

Nesta pesquisa procurou-se determinar a melhor dotação de àgua, segundo a evaporação do tanque classe "A", para que se pudesse preconizar a irrigação da cana-de-acūcar, no estádio de soqueira, pelo método de gotejamento e suas implicações com o crescimento e a produtividade.

Adotou-se para o experimento, o delineamento de blocos casualizados com 4 tratamentos e cinco repeticões. A variedade usada foi a NA 56-79. O plantio foi feito em 14/ 04/1976, e a colheita da soca e ressoca em 05/07/1978 e 28/ 08/1979, respectivamente.

A irrigação nos tratamentos foi realizada por gotejamento, e sua dotação se baseou na evaporacão do tanque Classe "A" (ECA). Assimos tratamentos A, B, C e D correspon diam às parcelas que recebiam, respectivamente, 1.0 ECA; 0.8 ECA; 0.6 ECA, e 0.0 ECA, tanto na cana soca como ressoca. Cor 
xi i

relacionou-se o crescimento com uma funcão de clima, denomina da "Grau dia corrigido para Fotoperiodo" - (GD).

A altura total de água recebida pela cana soca no período foi de $1623 \mathrm{~mm}$ e na cana ressoca $1866 \mathrm{~mm}$, sendo ne cessários 11,6 mm de água para produzir uma tonelada de canal ha e $77,5 \mathrm{~mm}$ para a producão de uma tonelada de POL/ha na soca.

Para a ressoca foram necessārios $14,8 \mathrm{~mm}$ para produzir uma tonelada de cana/ha e $93,7 \mathrm{~mm}$ para producão de uma tonelada de POL/ha. Confirmou-se que a magnitude do cres cimento é um dos indices indicativo do potencial de producão da cana.

Concluiu-se que a irrigação não deve ser recomendada em soqueira de cana-de-açúcar, nas mesmas condicões de clima e solo constantes deste experimento.

Verificou-se que houve uma correlação entre de senvolvimento vegetativo da soca e ressoca e a funcão de clima denominada "Grau Dia Corrigido para Fotoperīodo" (GD), constituindo-se tais relacões básicas de dependēncia clima $x$ crescimento, indicadores básicos para previsão de corte e de rendimento agricola. 
UTILIZATION OF THE CLASS "A" PAN FOR CONTROLLING DRIP IRRIGATION OF SUGARCANE (Saccharum spp.) RATOON CROPS

\author{
Author: Miguel Viscaino Carretero \\ Adviser: Dr. Rubens Scardua
}

\title{
SUMMARY
}

In this research, an attempt was made to define the best amount of water, determined by the evaporation of a class "A" pan, in order to establish the irrigation of sugar-cane ratoon crops by the drip method, and its implications on growth and yields.

A randomized block design with four treatments and five replications was adopted. The variety chosen was NA 56-79, which was planted on April 14, 1976 and the harvest of first and second ratoons was done on July 5, 1978 and August 28, 1979, respectively.

The treatments were drip-irrigated, and the amount of water was based on the evaporation of the class "A" pan $(E C A)$. Treatments $A, B, C$ and $D$ corresponded to plots which received 1.0 ECA, 0.8 ECA, 0.6 ECA and 0.0 ECA, first and second ratoons. 
Growth was correlated with a climate function called "Degrees-day Corrected for Photoperiod" - (GD).

Total water height received by the first ratoon cane during the period was $1623 \mathrm{~mm}$, and the second ratoon $1866 \mathrm{~mm} ; 11.6 \mathrm{~mm}$ of water was necessary to produce 1 ton cane/ha, and to produce 1 ton pol/ha, in the first ratoon crop, $77.5 \mathrm{~mm}$ was riecessary. In the second ratoon crop 14.8 $\mathrm{mm}$ were necessary to produce 1 ton cane/ha, and $73,7 \mathrm{~mm}$ to produce 1 ton pol/ha. It was confirmed that growth magnitude is an index of cane growth potential.

It was concluded that irrigation is not recommended for sugarcane ration crops under climate and soil conditions to those of this experiment.

It was shown that there was a correlation between vegetative development of first and second ratoons and the climate function called "Degrees-day Corrected for Photoperiod" (GD), and that basic dependence relationships such as climate $x$ growth are fundamental for the prediction of harvest time and agricultural yields. 


\section{INTRODUÇAOO}

Sendo o Brasil um dos maiores produtores de ca na-de-açucar, com uma ārea plantada de 2.607 .638 ha e uma pro dução de 148.650 .563 toneladas em 1980, e tendo em vista a im portāncia do àlcool, atualmente, como combustível de veículos automotores, considera-se a cana como uma das principais culturas exploradas no pais.

No àmbito estadual, São Paulo é o maior produtor, com uma ārea de 947.750 ha e uma produção de 70.728 .788 toneladas de cana e 3.914.816 toneladas de açúcar na safra $81 / 82$ (MENEZES, 1982).

Apesar desta-importāncia, a produtividade da lavoura canavieira no pais é baixa, em torno de 54 ton/ha/ano (67 ton/ha/ano para o Estado de São Paulo). Nos paîses onde a cultura da cana-de-açúcar é desenvolvida com o emprego de alta tecnologia, como na Austrālia e África do Sul, por exemplo, as produtividades médias atingem aproximadamente 100 ton/ 
ha/ano.

Dentre as técnicas de operação de cultivo responsáveis por este alto rendimento, destaca-se o uso da irrigação. O sistema mais difundido naqueles paîses é o de irrigação por sulcos de infiltracão, que também ocupa a maior par te das āreas irrigadas nas regiões semi-āridas do nordeste do Brasil. No Estado de São Paulo, os sulcos de infiltração, re ceberam maior receptividade, mas são pouco usados, pois além da baixa eficiência, requerem sistematizacão do terreno. A í rigacão por aspersão, que se apresenta tecnicamente mais indi cada, tem um alto custo de implantação e exige mão-de-obra qua lificada.

Na década de 60, surgiu um novo mētodo de apli cacão de água com boas perspectivas de uso, chamado gotejamen to, que tem mostrado vantagens nas regiões āridas, onde há problemas de escassez de āgua, salinizaça do solo e alta taxa de evapotranspiracão. E um sistema de alta eficiēncia, a u tomatizado, exigindo pouca mão-de-obra e facilitando o emprego de adubos líquidos ou dissolvidos em àgua. As chuvas, pela sua irregularidade ou deficiéncia em determinados períodos da cultura, tem prejudicado seu rendimento. Por outro lado a temperatura do ar, abaixo de certos limites também afeta. o rendimento da cana-de-açūcar.

Para cada processo fisiológico e para cada tipo de planta há uma faixa térmica dentro da qual o processo 
atinge sua maior intensidade. A ação da temperatura no desen volvimento da planta pode ser quantificada pelo acúmulo diário de graus a partir de uma temperatura base abaixo da quál o crescimento vegetal é severamente afetado. Um estudo de exigēncias térmicas permite estimar o desenvolvimento da cana-de-açūcar.

0 estudo do consumo de água pela cana-de-açúcar, e da temperatura para atender a sua exigência em cada e $\underline{s}$ tādio de desenvolvimento, justifica-se plenamente, tendo em vista o elevado valor económico que a cana-de-acūcar tem re presentado ultimamente para o paîs.

Considerando-se os problemas aqui ventilados e a necessidade de maiores informacões sobre a cana irrigada por gotejamento, foi desenvolvido este trabalho com o objetivo principal de determinar o consumo de água a várias dotacões com base na evaporação do tanque classe $A$ e verificar o desenvolvimento vegetativo, o rendimento da cultura da cana e a influēncia da temperatura ambiente nesse desenvolvimento. 
4.

\section{REVISATO DE LITERATURA}

\subsection{Irrigação por gotejamento}

A caracteristica principal desse método de irrigacão é distribuir a àgua no terreno por meio de dispositivos denominados gotejadores, através dos quais a água cai em gotas, com pressão virtualmente nula.

GOLDBERG e SHMUELI (1971) a firmam que o umidecimento intencional não uniforme da superfície do solo é uma característica da irrigacão por gotejamento. Afirmam ainda que existe um gradiente constante da tensão de umidade do so10, desde a linha de gotejadores até a margem da ārea molhada.

KENWORTHY (1972) afirma que o método de irriga cão por gotejamento toma por base o conceito de que o melhor uso da água disponível no solo e o melhor desempenho da plan- 
ta poderão ser obtidos se evitado qualquer défice de àgua, mantendo sempre condicões favoráveis de umidade no solo no vo lume de maior atividade das raizes.

$$
\text { HALEVY et alii (1972) afirmaram que as raizes }
$$

desenvolvem-se densamente, dentro dos limites do volume do so 10 molhado no gotejamento, e apresentam grande atividade de absorção de àgua.

GOLDBERG et alii (1976), destacam que a irriga ção por gotejamento não é somente outro método de irrigação, mas sim um novo conceito da agronomia para as culturas, sob condições de controle da umidade do solo, fertilização e sali nidade, época de colheita e qualidade de produção.

\subsection{Fatores climáticos}

Borden et alii citado por HUMBERT (1968) estudando o crescimento da cana em dois solos distintos, concluiram que existe uma correlação entre o crescimento semanal e a temperatura efetiva medida em graus dia. Este estudo mostrou claramente a influéncia que os fatores climáticos tem sobre a produção.

A temperatura é um dos fatores do clima mais importantes, e é ela que, juntamente com a precipitacão, quan tifica e qualifica as espécies vegetais no globo terrestre.

FAUCONNIER e BASSEREAU (1970) afirmam que o 
crescimento da cana é nulo a $15^{\circ} \mathrm{C}$, praticamente nulo a $18^{\circ} \mathrm{C}$ e não se estabelece senão acima de $20^{\circ} \mathrm{C}$. A cada lugar corresponde um rendimento māximo, que depende das condições climāt cas do ano. Afirmam a inda que a absorcão da āgua pelas raízes. é māxima de 28 a $30^{\circ} \mathrm{C}$, nula de 10 a $15^{\circ} \mathrm{C}:$ é a seca fisioTögica conhecida como inverno nas regiões subtropicais. Estes mesmos autores afirmam a inda que a temperatura para germi nação depende da variedade, sendo lenta abaixo de $20^{\circ} \mathrm{C}$, ōtima entre 26 e $33^{\circ} \mathrm{C}$, e prejudicial além de $40^{\circ} \mathrm{C}$. O crescimento é consideravelmente aumentado a medida que a temperatura média se eleva acima de $20^{\circ} \mathrm{C}$; é assim que a elongação da cana e o volume do colmo são quatro vezes mais efetivos a $25^{\circ} \mathrm{C}$ que a 21.

Supondo uma variação linear na distribuição da temperatura do ar, desde a māxima até a mīnima, VILLA NOVA et a Zii (1972) obtiveram, geometricamente uma fórmula para o cōm puto de graus dia, para o caso em que a temperatura base é me nor que a temperatura minima e uma outra para temperatura base menor que a máxima $\varepsilon$ maior que a mīnima.

DEMETRIO (1978) ajustou os dados de graus dia, acumulados para cana planta, à curva de Funcão Logística, con cluindo que os mesmos correlacionavam-se perfeitamente com os dados de crescimento do colmo, constituindo-se em importante elemento para estimar tal característica e, consequentemente, o potencial de produção de uma região com relação ao seu va- 
lor térmico.

MANIERO (1980), estudando treze variedades de cana-de-açucar nos municipios paulistas de Macatuba e Pradópolis, concluiu que existe correlação entre graus dia e crescimento da planta, e que esta relação é mais satisfatória após a cana-de-açúcar atingir a altura aproximada de $30 \mathrm{~cm}$. Concluiu, também, de seus ensaios que os Graus Dia Acumulados constituiram-se em elementos importantes para estimar o desen volvimento da cana-de-açūcar e o potencial de producão de uma região correlacionado com o seu indice térmico.

\subsubsection{Evapotranspiração/Evaporação}

FRITSCHEN e SHAW (1961) chegaram a conclusão de que o tanque classe $A$ pode ser usado para estimar a evapotranspiração, desde que se conheça as relacões entre a perda de àgua da cultura e do tanque.

Fuhriman e Smith, citados por KRUTMAN (1963), obtiveram os seguintes resultados em cana para a relação uso consuntivo/evaporaçã : 0,52 para os dois primeiros meses após o plantio, atingindo o máximo de 0,91 e decrescendo para 0,52 na época anterior à colheita. o valor médio encontrado foi 0,71 .

KRUTMAN (1963), em trabalho realizado na Estação experimental do Curado - PE, visando obter dados para fi- 
xar o intervalo de regas na cana, encontrou a relacão uso con. suntivo/evaporação para o período de irrigacão, quando a cultura cobriu o solo, igual a 0,58 , sendo que para os meses de crescimento mais intenso, esta mesma relação foi igual a 0,65 . Cowan e Innes citados por KRUTMAN (1963) concluiram que a relação uso consuntivo da cana/evaporacão de uma superfície livre, era de ordem de 0,58 .

HARDY (1966) na ilha de Mauricio, empregando 6 lisimetros na cultura de cana, determinou que a evapotranspiração média anual foi de 1722,1518 e $1744 \mathrm{~mm}$, e que a quant $\underline{i}$ dade de àgua para cada tonelada de cana produzida foi de 11,9 $\mathrm{mm} ; 9,8 \mathrm{~mm}$ e $11,7 \mathrm{~mm}$ respectivamente para os anos de 1964,65 e 66 .

CHANG et alii (1967), no Havaī, em vārios projetos irrigados com diferentes dotações de àgua controlada pe 10 tanque de evaporação classe A, afirmaram que a colheita má xima foi obtida quando a evapotiranspiraça atual e potencial foram iguais. Isto dá validade à estreita correlação entre a evapotranspiração e a evaporação do tanque classe A. Afirmaram, ainda, que os princípios básicos que governama. evapotranspiração estão agora sendo usados para avaliar a àgua, os sistemas de distribuicão e determinar a sua distribuicão durante periodos de seca.

Experimentos conduzidos por THOMPSON (1967) em Natal, Africa do Sul, em que estudou as relacões entre a eva 
potranspiração potencial da cultura da cana e os fatores ambientais, mostraram a mesma confirmação jā alcancada por pesquisadores de outros paises, de que existe uma aproximaça praticamente igual entre os valores da evapotranspiração (Et) potencial medida e a evaporação (Eo) do tanque Classe A. Essas medidas, para o período de janeiro a julho de 1963, foram de $3,80 \mathrm{~mm} / \mathrm{dia}$ de Et potencial, obtendo uma relação média de Et/Eo de 0,99 e, uma reíação média da Et/Eo de Penmar de 1,13. Verificou ainda que as médias semanais da Et diāria ex cediam as quantidades prováveis em termos de radiação líquida medida isoladamente, e que o efeito da existéncia de considerável energia defectiva tem, portanto, sido sugerido $\because$ como principal motivo da elevada relação Et/Eo.

CRUCIANI (1972), em experimento realizado na Usina Monte Alegre em Piracicaba-SP, encontrou as seguintes correlações entre a evaporação do tanque Classe A e a evapotranspiração da cultura, determinada pelo método do balanço hidrico.

TABELA 1. Correlações ER/Eo (CRUCIANI, 1972).

\begin{tabular}{cccc}
\hline Estädio & $\begin{array}{c}\text { Idade em } \\
\text { meses }\end{array}$ & $\begin{array}{c}\text { ER } \\
\text { mm/dia }\end{array}$ & ER/Eo \\
\hline 10 & $0-6$ & 1,33 & 0,420 \\
20 & $6-12$ & 3,42 & 0,760 \\
30 & $12-16$ & 2,35 & 0,790 \\
\hline
\end{tabular}

Variedade da cana: IAC 50-134. 
10.

FOGLIATA (1974), na Argentina, estudando a eva potranspiração média na cultura da cana durante 10 meses, encontrou 4,36 mm/dia, com um máximo de 6,09 e um minimo de $3,46 \mathrm{~mm} / \mathrm{dia}$. Verificou que a cultura necessita de 12,55 a $14,90 \mathrm{~mm}$ de àgua para produzir uma tonelada de cana e 104,9 a 144,2 mm de àgua para produzir uma tonelada de açūcar. Em ou tro experimento constatou que a cultura de cana necessita de irrigação quando o solo atinge 1 à 2,5 atmosferas de tensão de āgua. Verificou ainda que a evapotranspiraça potencial da cana-de-açūcar em Tucumān foi $4,42 \mathrm{~mm} / \mathrm{dia}$ na primavera, $6,09 \mathrm{~mm} / \mathrm{dia}$ no verão e $3,46 \mathrm{~mm} / \mathrm{dia}$ no outono, obtidos em 1 is $\underline{\mathrm{I}}$ metros e em condições de campo. O total de água de uso consuntivo foi de $1.331,60 \mathrm{~mm}$.

SCARDUA e SOUSA (1976) em experimento com cana-de-acuucar irrigada por gotejamento, e cujos tratamentos re ceberam quantidades de água em função da evaporação Eo do tan que classe $A$, nos niveis 1,0 Eo; 0,8 Eo; 0,6 Eo; 0,0 Eo, concluiram que o tratamento 0,6 Eo deve ser recomendado para a irrigação da cana nas condicões do experimento e do método em pregado.

SOUSA (1976a), em experimento realizado na Estação Experimental de Cana-de-Açúcar no municipio de Araras, $S P$, encontrou as seguintes correlações entre a evaporaça do tanque Classe $A$ e a evapotranspiracão real da cultura no tratamento 3 , determinada pelo método do balanço hídrico no campo . 
TABELA 2. Correlações ER/Eo (SOUSA, 1976a)

\begin{tabular}{cccc} 
Estādio & $\begin{array}{c}\text { Idade em } \\
\text { meses }\end{array}$ & $\begin{array}{c}\text { ER } \\
\text { mm/dia }\end{array}$ & ER/Eo \\
\hline 10 & $4-6$ & 3,413 & 0,597 \\
20 & $6-12$ & 3,453 & 0,720 \\
30 & $12-14$ & 2,379 & 0,705
\end{tabular}

Variedade da cana empregada: CB 41-76

Caracterizou os seguintes estádios por períodos:

10 estádio - da emergència das plantas até o 60 més;

20 estādio - periodo que vai do 70 até o 120 més; e 30 estādio - perỉodo que vai do 120 até o 140 mès.

No tratamento 3 a irrigação era feita quando 0 solo perdia $75 \%$ do total de àgua disponìvel. SOUSA (1976b) em Araras, SP, estudando a cana-de-açūcar irrigada por sulcos de infiltracão, encontrou coeficientes médios de proporciona- 
lidade (k) entre evapotranspiração real (ER) e a evaporação (Eo) do tanque Classe $A$ de $0,471,0,675$ e 0,655 para 0 10, 20 e 30 estádios do desenvolvimento vegetativo, respectivamen te.

\subsection{Sistema radicular}

INFORZATO e ALVAREZ (1957) estudando, o sistema radicular da cana-de-açúcar var. Co 290, em condições normais de cultivo, em solo de terra roxa legitima no municipio de Araraquara; a uma profundidade de $30 \mathrm{~cm}$, encontraram $41 \%$; $71 \%$ e $66 \%$ das raizes aos 6,12 e 18 meses, respectivamente. Eles concluiram que a maior quantidade de raizes se encontra localizada nos primeiros $30 \mathrm{~cm}$ de solo.

KRUTMAN (1962), em seu trabalho com cana sob condicões naturais em Curado, PE, concluiu que, na cana soca, - sistema radicular está bem mais desenvolvido, e portanto, explora maior volume de terra. 0 mesmo não ocorre com a cana planta, na qual o sistema radicular se encontra em desenvolvi mento, e o solo sofre compressão continua.

HUMBERT (1968) confirma as pesquisas de diferentes autores, que afirmam ser nos primeiros $20 \mathrm{~cm}$ que se concentram $50 \%$ das raizes, aos $30 \mathrm{~cm} 70 \%$; aos $40 \mathrm{~cm} 82 \%$, e nu ma espessura de $60 \mathrm{~cm}$ de profundidade se concentram $85 \%$ das raizes. 0 sistema radicular da soca tem menor desenvolvimen- 
to que o da cana planta, e as rajzes desta permanecem vivas por um longo periodo depois do corte; mas gradualmente morrem a medida que se forma um novo sistema radicular na cana soca. SCARDUA e SOUSA (1976), estudando o comportamento da cultura da cana-de-açūcar irrigada por gotejamento em Araras-SP, e as diferentes dotações de àgua segundo a evaporação do tanque Classe $A$, determinou, para efeito da irriga ção, que $80 \%$ se localizaram de 0 a. 0,60 m de profundidade.

SOUSA (1976b) em Araras-SP, estudando a cana-de-açúcar irrigada por sulcos de infiltracão, encontrou a 40 cm e na faixa seguinte, até os $60 \mathrm{~cm}$ de profundidade, um enraizamento médio de $62,40 \%$ e $82,20 \%$ respectivamente, havendo apenas uma diferença menor para o tratamento não irrigado.

\subsection{Crescimento}

KRUTMAN (1962), estudando o crescimento da cana sob condições naturais na Estação Experimental do Curado- PE, determinou três estádios bem distindos de elongacão na cana planta: a) uma elongação māxima dos 3 aos 5 meses; com a média acima de $10 \mathrm{~cm}$; b) dos. 5 aos 7 meses elongacões semanais compreendidas entre 4 a $10 \mathrm{~cm} ; \mathrm{c}$ ) valores semanais abaixo de $4 \mathrm{~cm}$, do 70 més em diante. Na soca foram observados: a) dos 2 aos 3 meses, a elongação semanal foi de 9 a 11 cm; 
b) entre 4 e 5 meses de elongacão foi de 5 e $6 \mathrm{~cm} ; \mathrm{c}$ ) dos 5 aos 7 meses houve um decréscimo para 1 e $3 \mathrm{~cm}$. A elongacão máxima ocorreu dos 2 aos 3 meses.

ROBINSON (1963), estudando o efeito da. tensão da umidade do solo sobre a elongacão da cana no Havaí, concluiu que esta declina no momento em que a tensão de umidade do solo aproxima-se de 2 atmosferas a $30 \mathrm{~cm}$ de profundidade. Haveria uma real redução na taxa de crescimento somente depois que a tensão do solo ultrapassasse a 2 atmosferas. Ele recomendou que a irrigacão seja feita sempre que a tensão da umidade do solo a $30 \mathrm{~cm}$ de profundidade, se aproxime de 2 atmosferas.

ROVINSON et alii (1963), em experimentos com cana irrigada, no Hava $\bar{i}$, concluiram que o comprimento do colmo é um indicador do efeito do défice de umidade do solo sobre o rendimento da cana-de-açúcar e que o decréscimo no comprimento do colmo ocorreu sempre que as tensões de umidade do solo excediam a 2 atmosferas.

Temperatura, luz e umidade são os principais fatores climáticos que controlam o crescimento da cana. E uma planta tropical, desenvolvendo-se melhor em regiões de temperaturas elevadas e āreas ensolaradas. Mangelsdorf, citado por HUMBERT (1968), caracteriza um clima ideal para a produção da cana-de-açūcar:

a) um período de crescimento com verão longo e 
quente e precipitação adequada;

b) fase de amadurecimento e colheita razoavelmente seca, ensolarada e fria, mas livre de geada;

c) ausēncia de furacão e tempestades.

Stender, citado por HUMBERT (1968), mostrou a correlacão entre o crescimento e diāmetro do colmo para a tem peratura no Havai. Suas medidas mostraram que o crescimento dos colmos primārios no inverno foi reduzido a um terco do crescimento no verão.

EAVIS (1972), em Barbados, cultivou duas varie dades de cana em lisimetros contendo, ambos, solos argilosos Montmoriloniticos e caoliniticos. Durante um periodo de seis meses as diferencas entre crescimento e perfilhamento no tratamento em que o lençol freático foi mantido a $15 \mathrm{~cm}$ abaixo da superficie do solo e o tratamento na capacidade de campo (drenado desde $80 \mathrm{~cm}$ abaixo da superficie do solo) esteve insignificante em um outro tipo de solo ou variedade de cana. Este resultado pode ser comparado com outro trabalho do mesmo autor, quando o solo inundado até a superfície do terreno, afetou adversamente a taxa de elongacão e o perfilhamento. Du rante a seca, a elongacão total (colmo e ponta da folha) foi de $200 \%$ maior no caolinitico e $50 \%$ no montmorilonitico, para as plantas antecipadamente inundadas.

FOGLIATA (1972), estudando a irrigacão da cana -de-açūcar em Tucuman, com a var. NA 56-79 e irrigacão por sulcos de infiltraça, concluiu que os melhores resultados de 
elongação do colmo $(\mathrm{cm})$, foram obtidos com as irrigações realizadas quando ainda restavam $40 \%$ da ägua disponivel no solo, e que correspondia a tensões de àgua entre 1 a 2,5 atmosferas. Em um outro experimento com a var. NA 56-30, em diferen tes nỉveis de umidade disponīvel para o crescimento da cana, constatou que a relacão entre os valores da tensão semanal de elongação do colmo, sugerem que o momento ótimo para a irriga cão seria quando a tensão da água do solo atingisse entre 1,00 a 2,5 atmosferas. Ele afirmou que nova irrigacão deve ser provida quando o crescimento semanal cair próximo de $50 \%$. SCARDUA e SOUSA (1976), em experimento realiza do em Araras-SP, com a var. CB 4.1-76 e irrigada por gotejamen to concluiram que a medição do comprimento do colmo até a 1 ạ aurícula visível, mostrou ser o parámetro fisiológico mais in dicativo na produção da cana.

SOUSA (1976a) em Araras-SP, concluiu que o nūmero de brotos ou perfilhos, diāmetro e nūmero de colmos na colheita, são características que independem dos regimes de umidade estudados, mas que o mesmo não ocorre com o crescimen to do colmo medido na primeira auricula visivel. Ele afirma ainda que o melhor indice para se determinar o potencial de produção da cana é a magnitude do crescimento do colmo, e isto também foi confirmado por ele mesmo em SOUSA (1976b). 
2.5. Necessidade de irrigação, relacionada com a produção

A água necessária para uma cultura em regiões úmidas, depende mais da frequência e intensidade das precipitações mensais, durante o período de crescimento, do que da pre cipitação total anual. Portanto a necessidade de irrigaçãones sas regiões varia de um ano a outro, com as chuvas que caem durante a época de desenvolvimento das plantas (ISRAELSEN, $1963)$.

THOMPSON e COLLINS (1963), nas Costas de Natal encontraram uma média inferior a 29,65 ton de cana ha/ano, como resposta a irrigação suplementar.

ROBINSON et alii (1963) estudando a utilização do tanque de evaporação Classe A para o controle da irrigação na cana-de-açúcar no Havaí, onde realizou experimentos com di ferentes dotações de àgua, conclúiram que 0,85 Eo produziuóti mo rendimento sob as condições estudadas, e que a irrigação e a densidade da cultura, ambos causaram diferenças altamente significantes no rendimento da cana.

ISRAELSEN e HANSEN (1965) consideraram que as plantas podem extrair até $75 \%$ da àgua disponível no solo sem muito esforço. Consideram também que as culturas em seu perīo do de desenvolvimento, necessitam continuamente de àgua, mas a grandeza de suas necessidades varia com a cultura, idade da mesma, a temperatura e as condições atmosféricas, todos eles fatores variāveis. 
THOMPSON et alii (1967) estudando a irrigação suplementar em dois solos de Natal,em cana-de-açūcar, obtive ram um rendimento de 121,8 ton/ha em solo arenoso e irrigado, contra 76,6 ton/ha em cana não irrigada. No solo argiloso o rendimento foi de 121,8 ton/ha na cultura irrigada contra 64,8 ton/ha na não irrigada. Eles concluîram que quando a água disponível para a irrigação suplementar está limitada, os solos pesados deverão ter preferēncia à irrigação em relação aos arenosos.

A resposta à irrigação na cultura da cana depende do estádio de desenvolvimento em que ela se encontra no momento da aplicação da água. Com base nesse conhecimento Shaw, citado por CAMPBELL (1968), trabalhando nas planiciesda Jamaica, relatou que o aumento de produção na irrigação é maior no primeiro terço de uma cultura anual do que no ūitimo terço. sta é uma descoberta importante,especialmente quando a irrijação suplementar é participante e quando há limitação de equi pamento ou àgua, e é obviamente importante para decidir em qual estádio de crescimento se dará o último retorno a irriga ção. Segundo HUMBERT (1968), a frequēncia das regas dependedo estadio de desenvolvimento da cana. Na germinação requer regas rápidas e frequentes, e a medida que as raízes se desenvolvem e se aprofundam, as regas serão mais espaçadas e pesadas. Quando a cana chega a seu desenvolvimento total aconselha - se regar logo que a umidade disponivel do solo baixa a $50 \%$ e, ao aproximar-se a maturidade,deve-se aumentar o intervalo entre 
regas para reduzir o crescimento vegetativo, desidratar a cana e forçar a conversão dos açūcares redutores à sacarose recuperāvel.

ISOBE (1969) estudando a eficiēncia do uso da āgua na irrigação da cana no Hava î, determinou que ela varia de 2,13 a 2,67 ton de cana/ha para cada $25 \mathrm{~mm}$ de àgua aplicada e de 0,29 a 0,35 ton de açūcar/ha em média. A produção mé dia do projeto foi de 341 ton de cana/ha e 46,5 ton açucar/ha. BARRETTO et alii (1971), estudando a cultura da cana irrigada por sulcos de infiltração em solo latossol roxo, no Estado de São Paulo, obtiveram sensível aumento de pro dução, ou seja, 126,8 e 123,0 ton/ha, para as var. Co 419 e CB 41-76 respectivamente e 82,3 ton/ha para as mesmas variedades, quando não irrigadas. A produção de açūcar para os tratamentos irrigados foi de 16,1 e 15,1 ton/ha, e para os não irrigados 9,1 e 10,0, respectivamente para as mesmas variedades.

EARLY (1974) realizou dois tipos de experimentos em cana-de-açūcar nas filipinas, com trés e seis níveis de dotaç̃es de āgua, com o fim de verificar o rendimento. Os experimentos irrigados apresentaram um rendimento máximo de 12,70 ton/açucar/ha sobre os não irrigados, quando realizados na estação experimental. Provas de campo de aplicação de āgua com diferentes condições climāticas, de solo e culturais, foram realizadas nas usinas, e o rendimento máximo foi 
de aproximadamente 3,0 ton de açucar/ha.

Em experimento realizado em Araras-SP, para ve rificar o comportamento da cultura da cana irrigada por gotejamento, submetida a diferentes dotações de àgua, SCARDUA e SOUSA (1976) determinaram, que o melhor aumento de produtividade foi encontrado quando se fornecia $60 \%$ da evaporação do tanque classe $A$, correspondendo a 32,84 ton/cana/ha e 4,85 ton/açücar/ha:

SOUSA (1976b) em Araras-SP, aplicando a irriga ção por sulcos de infiltração em cana-de-açúcar, necessitou de 11,89 mm de àgua para produzir 1 ton de cana, e 82,42 mm para produzir 1 ton de açucar. Os aumentos de rendimento, ob tidos nos tratamentos irrigados, indicam que o pontencial de àgua do solo deve ser mantido até um minimo de 1,2 atm. 0 me Thor tratamento apresentou um consumo médio de àgua de $3 \mathrm{~mm}$, com o total do período de $868 \mathrm{~mm}$.

DEMETRIO (1978), na pesquisa de cana planta,e $\underline{s}$ tudou o efeito da água do solo e da temperatura ambiente no rendimento agricola e industrial, observou que o tratamento $C$ que recebeu uma altura de àgua de irrigação correspondente a $60 \%$ da ECA, produziu 179,89 ton/cana/ha e 32,97 ton/açücar/ha, para uma produção de 148,84 ton/cana/ha e 26,60 ton/açúcar/ha no tratamento $D$ sem irrigação.

TULER et alii (1981) estudando o comportamento da cana irrigada por gotejamento em Campos, RJ, submetida a diferentes dotacões de água, e cujo fornecimento era controla 
do pela evaporação do tanque classe A, concluiram que não hou ve diferença significativa entre os tratamentos irrigados, mas estes diferiram significativamente do não irrigado. A variedade NA 56-79 apresentou uma produtividade média de 140 ton/ cana/ha e 23 ton/açúcar/ha quando irrigada, para uma produção de 107,40 ton/cana/ha e 18,82 ton/açücar/ha quando sem irriga ç̃o. 


\section{MATERIAL E METODOS}

\subsection{Material}

3.1.1. Descrição geral da ārea de estudo

o Municipio de Piracicaba, localiza-se. na região fisiográfica denominada Depressão Periférica Paulista, sub-região Médio Tieté, entre os paralelos $22030^{\prime}$ e 230 S Se tre os meridianos de 47030' e 48010'W.G., a altitude de $576 \mathrm{~m}$, conforme ilustra a Figura 1.

Segundo RANZANI (1976) isso significa que a ārea possui os atributos gerais dessa região, descrita por Mo RAES REgo (1932). A área do Município de Piracicaba é em sua maior parte constituída de sedimentos; apresenta zonas de in trusão de rochas básicas que marcam acentuadamente a topo- 


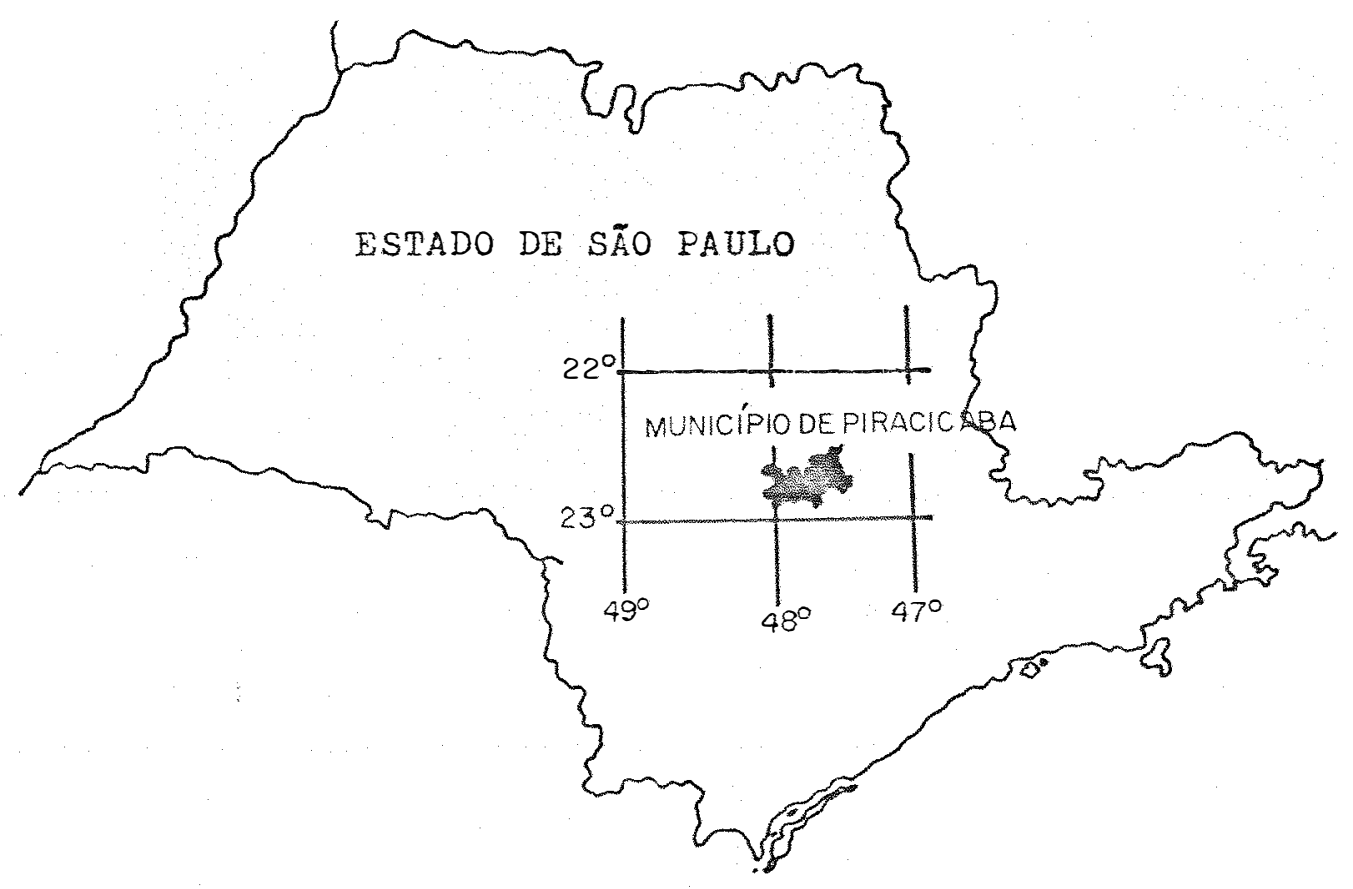

23.

FIGURA 1. Localização do Municīpio de Piracicaba no Estado de São Paulo.

grafia e que desempenham importante papel na vida económica regional, pelo fato de originarem terras adequadas à agricultura.

o clima da região, segundo o sistema kuppen, é do tipo Cwa: mesotérmico, de inverno seco, comtemperatura média do més mais frio inferior a 180 c e a média do més mais quente oscila entre 23 e 2400 , só atingindo 2200 acima de uma altitude de $800.00 \mathrm{~m}$. O total de chuva durante o més mais seco, não ultrapassa $30 \mathrm{~mm}$. A predomináncia da pluviosidade anual é de 1.200 a $1.300 \mathrm{~mm}$, porém no alto da Serra de Itaque ri sobe a $1.400 \mathrm{~mm}$ e mesmo $1.450 \mathrm{~mm}$, assim como desce a 1.100 mm, no canto SW da folha de Piracicaba (SETZER, 1946). 
Dados referentes a: evaporação do tanque Classe A, precipitacões pluviomētricas, temperaturas médias, máxi mas e minimas, de agosto de 1977 a setembro de 1979, no municîpio de Piracicaba, são apresentados na Tabela 3.

\subsubsection{0}

A presente pesquisa foi conduzida na ārea expe rimental do Departamento de Engenharia Rural da ESALQ cujo so 10 fora classificado por RANZANI et alii (1966) como pertencente à série Luiz de Queiroz, possuindo horizonte B textural. No trabaiho realizado pela COMISSÃO DE SOLOS DO SERVIÇO NACIONAL DEPESQUISA AGRONŌMICA (1960) este solo corresponde à unidade de mapeamento Terra Ro xa Estruturada (alfissol de acordo com a 7 ạ aproximação). A F $\underline{i}$ gura 2 mostra a localização desse solo no Estado de São Paulo.

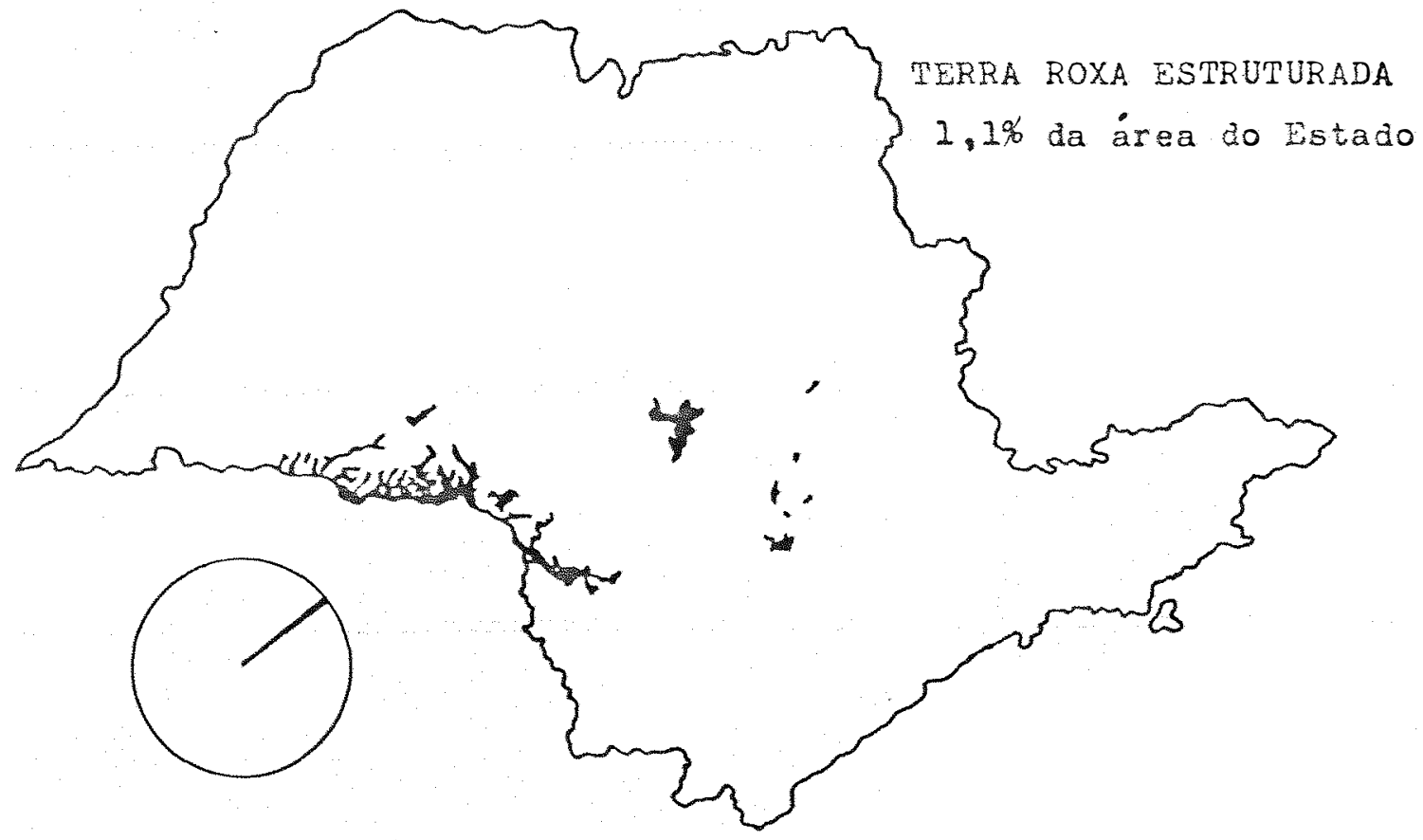

FIGURA 2. Mapa esquemātico mostrando a localização da Terra Roxa Estruturada no Estado de São Paulo, segundo a Comissão de Solos do Serv. Nac. de Pesq. Agr. (7960). 
TABELA 3. Dados meteorolōgicos durante o perīodo de irrigação da ārea experimental

\begin{tabular}{|c|c|c|c|c|c|c|}
\hline \multirow{3}{*}{1977} & \multirow{3}{*}{$\begin{array}{l}E C A \\
\mathrm{~mm}\end{array}$} & \multirow{3}{*}{$\begin{array}{c}E C A \\
\mathrm{~mm} / \mathrm{dia}\end{array}$} & \multirow{3}{*}{$\begin{array}{c}\text { Precip } \underline{i} \\
\text { tação } \\
\text { mm }\end{array}$} & \multicolumn{3}{|c|}{ * Temperaturas (OC) } \\
\hline & & & & \multicolumn{3}{|c|}{------------------} \\
\hline & & & & $\operatorname{Max}$ & $\operatorname{Min}$ & Média \\
\hline Agosto & 72.00 & 2.3 & 26.70 & 28.7 & 11.4 & 20.0 \\
\hline Setembro & 70.80 & 2.4 & 123.03 & 29.1 & 13.5 & 21.3 \\
\hline Outubro & 82.07 & 2.6 & 80.37 & 30.3 & 15.9 & 23.1 \\
\hline Novembro & 57.76 & 1.9 & 107.20 & 29,9 & 17.3 & 23.6 \\
\hline Dezembro & 20.80 & 0.7 & 332.71 & 28.0 & 16.2 & $22: 1$ \\
\hline \multicolumn{7}{|l|}{1978} \\
\hline Janeiro & 26.58 & 0.9 & 97.73 & 31.2 & 18.3 & 24.5 \\
\hline Fevereiro & 35.00 & 1.3 & 104.37 & 30.7 & 17.4 & 24.6 \\
\hline Março & 91.03 & 2.9 & 87.20 & 30.5 & 16.9 & 23.7 \\
\hline Abri & 96.58 & 3.2 & 5.06 & 29.0 & 12.4 & 20.7 \\
\hline Ma io & 88.92 & 2.9 & 81.09 & 25.7 & 9.8 & 17.8 \\
\hline Junho & - & - & 49.74 & 24.7 & 7.6 & 16.1 \\
\hline Julho & - & - & 75.00 & 26.3 & 8.3 & 17.2 \\
\hline Agosto & 92.83 & 3.0 & 0.60 & 25.9 & 8.2 & 17.0 \\
\hline Setembro & 86.80 & 2.9 & 158.06 & 26.8 & 11.7 & 19.3 \\
\hline outubro & 84.40 & 2.7 & 151.47 & 29.2 & 14.3 & 22.8 \\
\hline Novembro. & 28.00 & 0.9 & 190.70 & 28.7 & 16.5 & 22.6 \\
\hline Dezembro & 91.60 & 3.0 & 275.58 & 29.3 & 16.7 & 23.0 \\
\hline \multicolumn{7}{|l|}{1979} \\
\hline Janeiro & 76.80 & 2.5 & 128.65 & 28.6 & 15.7 & 22.2 \\
\hline Fevereiro & 100.80 & 3.6 & 102.62 & 30.7 & 16.7 & 23.7 \\
\hline Março & 82.80 & 2.7 & 85.87 & 29.6 & 15.1 & 22.3 \\
\hline Abri & 90.94 & 3.0 & 105.74 & 27.8 & 12.3 & 20.0 \\
\hline Maio & 123.40 & 4.0 & 87.02 & 26.0 & 11.1 & 18.5 \\
\hline Junho & 67.86 & 2.3 & 0.00 & 24.8 & .8 .1 & 16.4 \\
\hline Jutho & 47.71 & 1.5 & 23.30 & 24.1 & 8.3 & 16.0 \\
\hline Agosto & 86.21 & 2.8 & 77.83 & 27.6 & 11.8 & 19.7 \\
\hline Setembro & - & - & - & 26.1 & 13.3 & 19.7 \\
\hline
\end{tabular}

* Temperaturas do posto meteorológico central da ESALQ/USP. Os dados de evaporação do tanque classe A (ECA) e precipita ção foram fornecidos pelo posto meteorolōgico do departamen to de engenharia da ESALQ/USP, local do experimento. 
Na Tabela 4 estão descritas de forma sucinta as principais características gerais desse solo.

TABELA 4. Caracteristicas gerais da Terra Roxa Estruturada

Características Série Luiz de Queiroz (TRE)

Material de origem

Relevo

Profundidade

Natureza do horizonte B

Drenagem interna

Relação inf./deflūvio

Textura do horizonte $A$

Textura do horizonte $B$

Retenção de àgua (perfil)

Resist. à erosão

Itens. de uso agrícola eruptivas básicas

suav. ond. a ondulado

prof. a muito profundo

textural

boa

média

barro argiloso

argila

a 1 ta

média

muito alta

Fonte: RANZANI et arii (1966) e COMISSAO DE SOLOS DO SERV. NAC. DE PESQ. AGRON. (1960).

3.1.2.1. Características físicas e quĩmicas

As caracteristicas físicas do solo suporte do experimento, necessárias ao trabalho proposto foram:

a) Peso especifico aparente, determinado com auxilio do cilin dro de UHLAND, e que acusou o valor médio de $1,42 \mathrm{~g} / \mathrm{cm}^{3}$;

b). Peso específico real com o valor médio de $2,66 \mathrm{~g} / \mathrm{cm}^{3}$; 
c) Capacidade de infiltração do solo (Figura 3), determinada com o valor dos infiltrómetros de campo;

d) Curva característica da àgua do solo (Figura 4), determina da com auxilio das placas de RICHARDS (1947).

A capacidade máxima de retenção de àgua do so10, aqui referida como capacidade de campo ( $C C$ ), foi determinada no campo à profundidade de 0 a $0,60 \mathrm{~m}$ com resultado médio de $34,63 \%$ com base em volume e o ponto de murchamento per manente (PMP) correspondente a 75 atm de tensão foi de $22,60 \%$ com base em volume. Os resultados das análises química e mecànica se encontra na Tabela 5 .

TABELA 5. Caracterīsticas físicas e quỉmicas do solo da área experimental do Departamento de Engenharia Rural para a camada de 0 a $0,60 \mathrm{~m}$.

\begin{tabular}{|c|c|c|c|c|}
\hline \multirow{2}{*}{$\underset{\%}{\operatorname{Arg}}}$. & \multirow{2}{*}{$\underset{\%}{\operatorname{Limo}}$} & \multirow{2}{*}{$\underset{\%}{\operatorname{Areia}}$} & \multicolumn{2}{|c|}{ Peso especifico } \\
\hline & & & $\begin{array}{c}\text { Aparente } \\
\mathrm{g} . \mathrm{cm}^{-3}\end{array}$ & $\begin{array}{c}\text { Real } \\
\text { g. } \mathrm{cm}^{-3}\end{array}$ \\
\hline 60,16 & 8,00 & 31,84 & 1,42 & 2,66 \\
\hline
\end{tabular}

Teores trocáveis em me/100 g de terra

$\mathrm{pH} \quad$ M.O.

N. total

$\mathrm{K}_{2} \mathrm{O}$

$\mathrm{Ca}^{++}$

$\mathrm{Mg}^{++}$

$6,0 \quad 3,0$

0,154

0,034

0,29

3,72

1,20 


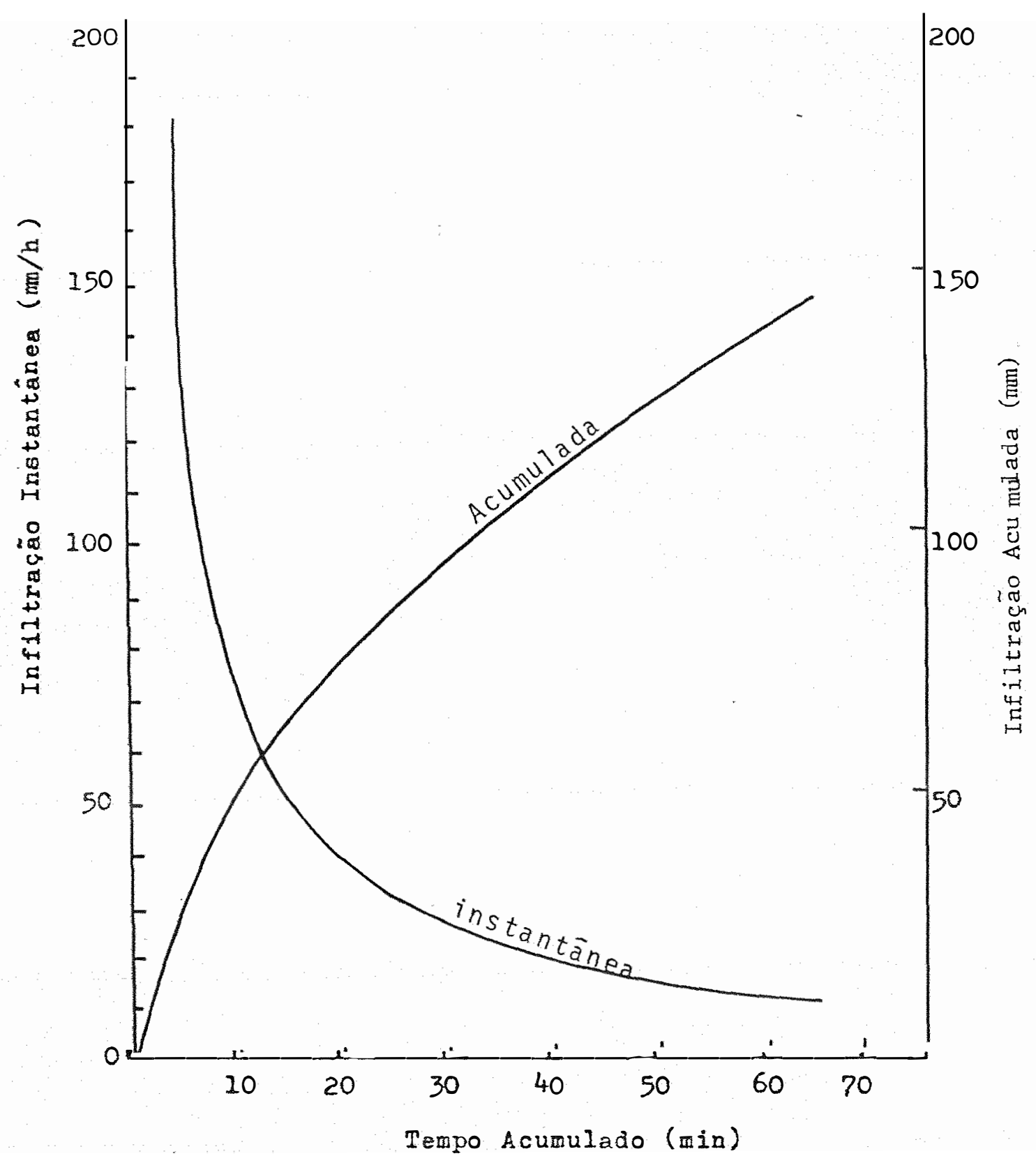

FIGURA 3. Capacidade de infiltração do solo. 
29.

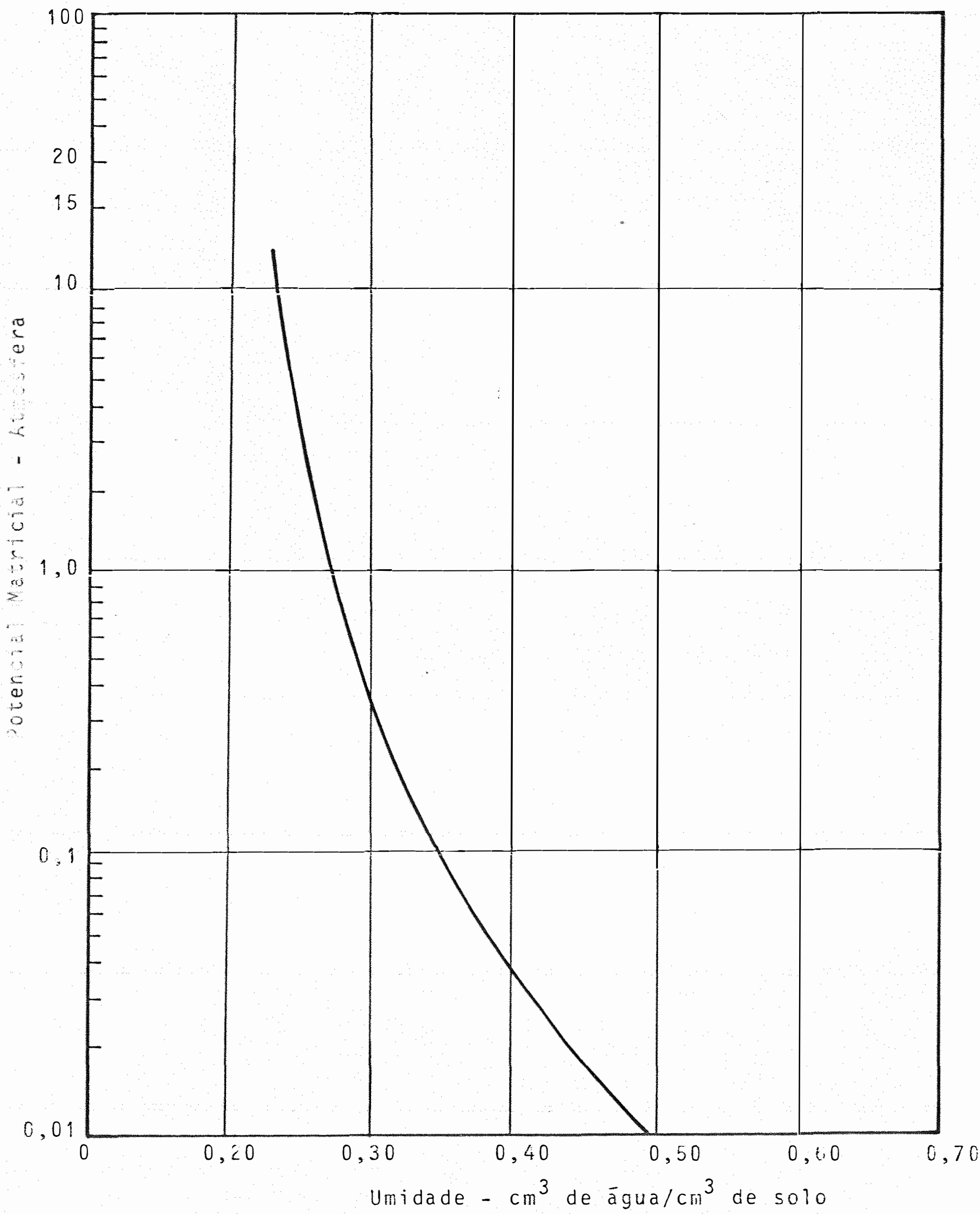

FIGURA 4 - Curva característica da àgua do solo 
3.1.3. Variedade da cana-de-açūcar

Utilizou-se a NA 56-79 que é uma variedade medianamente exigente em àgua e fertilidade, tombamento regular, despalha fácill, produtividade agrícola razoável no primeiro corte, mas possuidora de boa capacidade de brotação nas socas, mesmo em condições adversas, e rápido desenvolvimento, fato este que a torna indicada também para cana de ano em algumas regiões, sob certas condições favoráveis. Em produçãode açūcar por área, mostrou-se superior a variedade CB-41-76, considerada padrão, em $75 \%$ dos experimentos realízados.

Em anos de condições mais difíceis para matura ção, possui um teor de sacarose aparente (POL) superior a CB 41-76 em 33,20\% em maio, 19,10\% em julho e 9,70\% em setembroco mo se observa na Tabela 6 , o que demonstra sua alta precocida de.

TABELA 6. Comparação entre a POL das variedades CB 41-76 e NA $56-79$

\begin{tabular}{llll}
\hline Variedades & maio & julho & setembro \\
\hline CB $41-76$ & 10,22 & 12,74 & 14,52 \\
NA $56-79$ & 13,61 & 15,17 & 15,93 \\
\hline
\end{tabular}

Fonte: BASSINELO et alii (1976). 
3.1.4. Equipamento de irrigação

Utilizou-se no presente experimento, a irrigacão por gotejamento, cuja principal característica. é a coloca cão da água no solo em forma de gotas, através de dispositivos chamados gotejadores, com pressão virtualmente nula.

o sistema de irrigacão por gotejamento se compõe de um conjunto moto-bombas que recalca a àgua de um lago e através de uma tubulação subterrānea de ferro galvanizado, até o cabecal de controle composto de: filtro de areia, filtro de tela, injetor de adubo e sistema de controle de vazão. Do cabeçal de controle a água é conduzida pela linha mestre às linhas de derivação através de vālvulas métricas, que controlam a quantidade de ägua. Das linhas de derivação a água é conduzida às respectivas linhas laterais com gotejadores. Em cada linha de derivação há uma vālvula que controla a vazão da àgua.

A Figura 5 mostra com detalhes o sistema de ir rigação empregado.

3.1.5. Dados meteorológicos

Os dados referentes à temperatura, precipitação e evaporaça do tanque classe A foram obtidos no Posto Evaporimétrico, junto à-àrea experimental. Também foramutill zados os dados fornecidos pelo Posto Meteorológico Central da ESALQ/USP. 


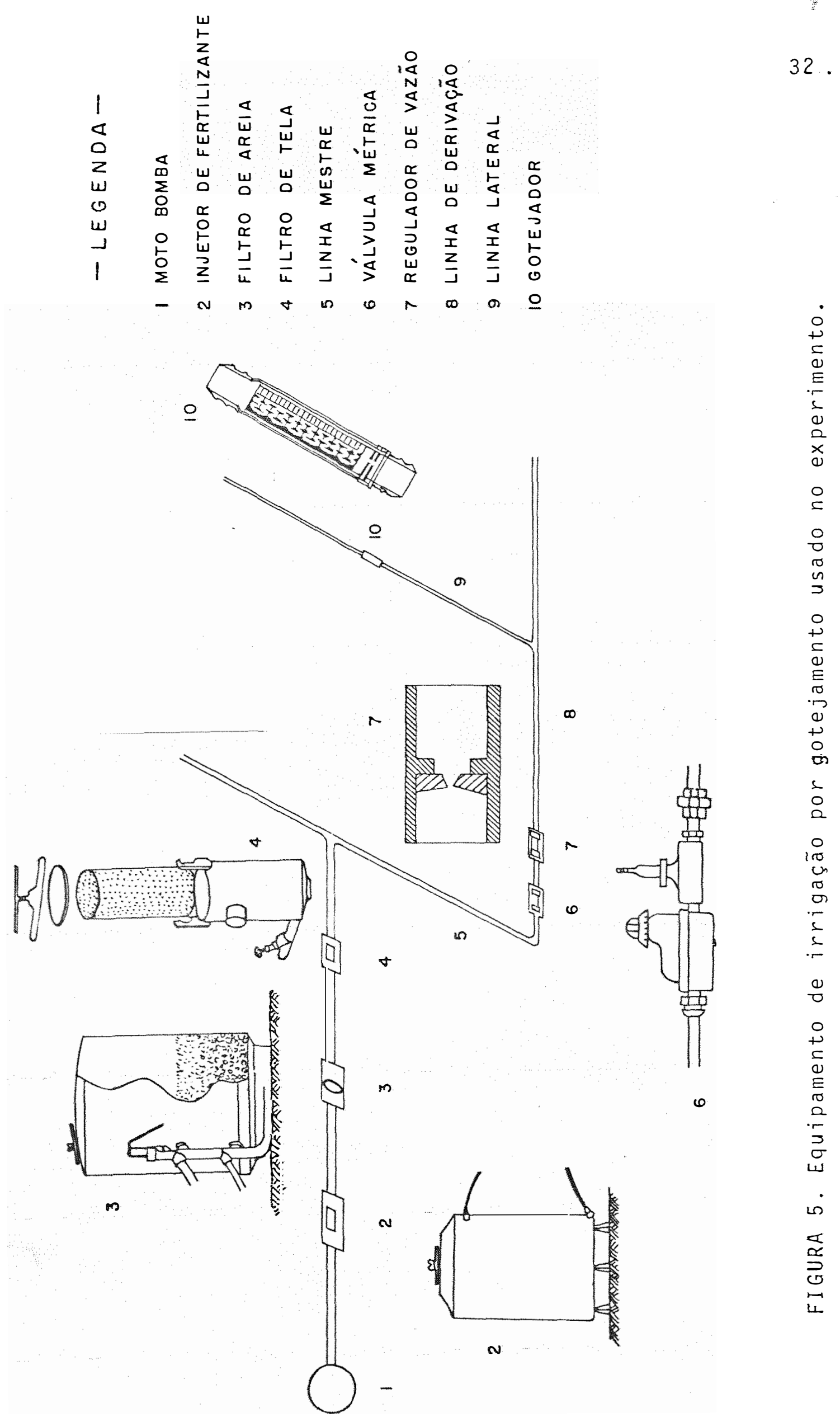




\subsubsection{Acessórios}

Foram utilizados trados convencionais para amos tragem do solo, balança de precisão e estufa 105 - 1100 C.

Para as medidas do potencial matricial da āgua do solo foram utilizados tensiómetros com vacuómetros de mercūrio, instalados na ārea do experimento às profundidades de 15,30 e $40 \mathrm{~cm}$.

\subsection{Métodos}

\subsubsection{Delineamento experimental}

o delineamento experimental foi em blocos casualizados, com quatro tratamentos e cinco repetições.

Os tratamentos foram definidos por regimes de àqua do solo proporcionados à cultura, através da irrigação por gotejamento, baseados no controle através da evaporação do tanque Classe $A$.

Tratamento 1 - Refere-se às parcelas que receberam irrigação, correspondente a $100 \%$ da evaporação do tanque Classe A.

Tratamento 2 - Refere-se às parcelas que receberam irrigação correspondente a $80 \%$ da evaporação do tanque Classe $A$. 
Tratamento 3 - Refere-se às parcelas que receberam irrigacão correspondente à $60 \%$ da evaporação do tanque Classe $A$.

Tratamento. 4 - Parcelas não irrigadas.

\subsubsection{Instalação do experimento}

o campo experimental foi preparado pelo método convencional, isto $\bar{e}$, arado e gradeado. Foram abertos pares de sulcos distanciados $0,90 \mathrm{~m}$ entre si. Cada par de sulcos tem um espaçamento de 1,80 m. Cada parcela (Figura 6) ocupa uma ārea de $20,00 \mathrm{~m}$ por $8,10 \mathrm{~m}$. Considerou-se como área ūtil a 1 inha dupla central que perfaz a ārea de. 54,00 $\mathrm{m}^{2}(20,00 \mathrm{x}$ $2,70 \mathrm{~m})$.

No plantio, 14 de abril de 1976, adubou-se segundo a formulação $80 \mathrm{~kg} \mathrm{~N} / \mathrm{ha}(40 \mathrm{~kg} / \mathrm{ha}$ no plantio e $40 \mathrm{~kg} / \mathrm{ha}$ seis meses após); $150 \mathrm{~kg} \mathrm{P} \mathrm{P}_{5} / \mathrm{ha}$ e $150 \mathrm{~kg} \mathrm{~K} \mathrm{~K}_{2} / \mathrm{ha}$.

Foram cortados toletes contendo 3 gemas e distribuidos dentro dos sulcos na base de 4 toletes por metro $1 \underline{i}$ near. A seguir, cobriu-se com uma camada de $8 \mathrm{~cm}$ de terra.

3.2.3. Condução da irrigação - cana soca e ressoca

A irrigação de uniformização do bulbo molhado iniciou-se em agosto de 1977 e de 1978, para a cana soca e ressoca, respectivamente. Com esta irrigacão, como preconiza 


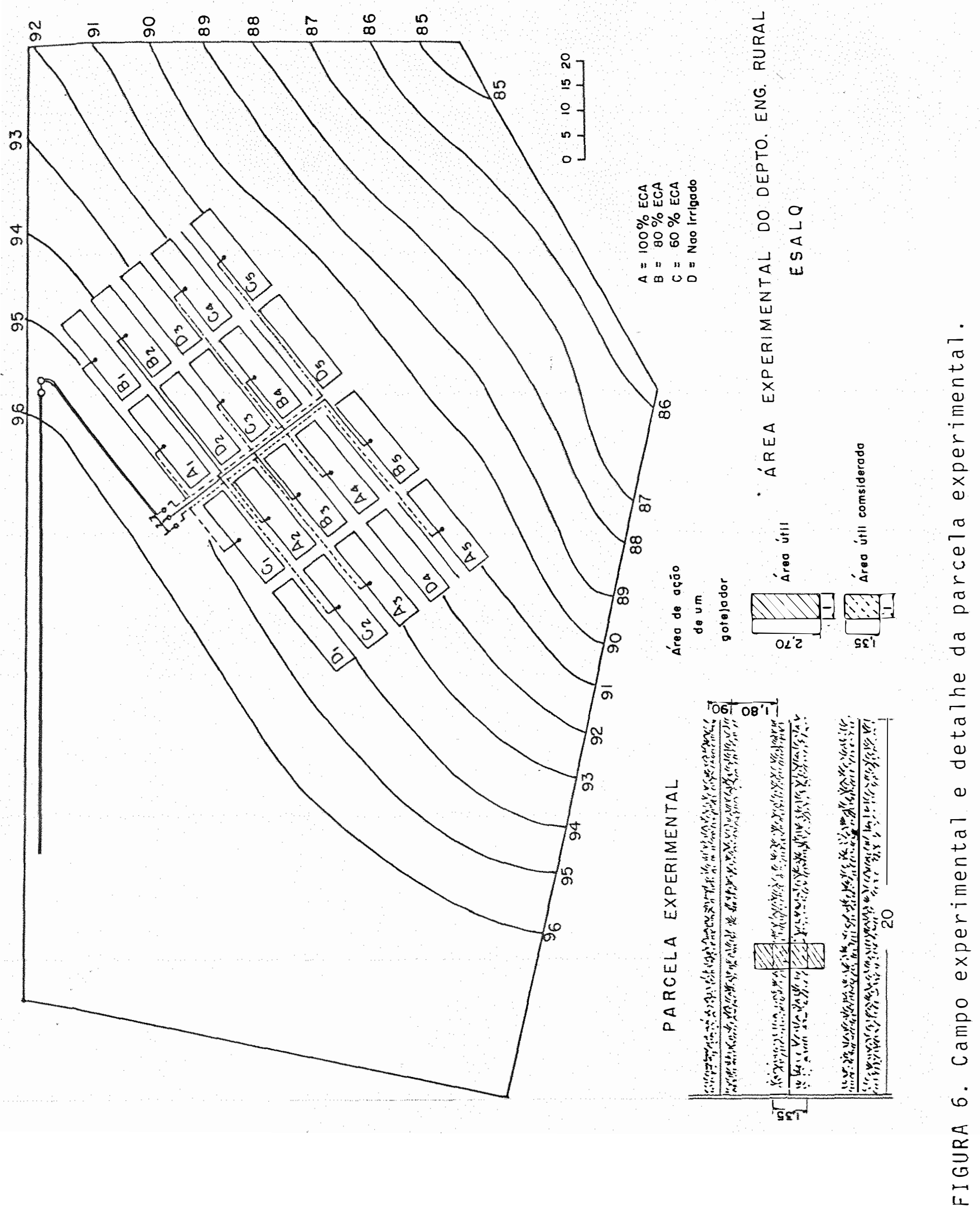


o próprio método, formou-se o bulbo molhado, que é o volume de solo servido de āgua por um gotejador o qual, em caso de cultivos em linha, é dado pela fórmula sugerida por JAIME (1973).

$$
B=D \cdot S \cdot P r
$$

onde:

$$
\begin{aligned}
B= & \text { volume do bulbo molhado de solo em litros } \\
D= & \text { espacamento entre linhas em metros } \\
S= & \text { espacamento dos gotejadores na linha em } \\
& \text { metros } \\
\operatorname{Pr}= & \text { profundidade radicular em milimetros } \\
0 & \text { volume de àgua necessārio para elevar a umi- }
\end{aligned}
$$

dade do solo à capacidade de campo no bulbo molhado, foi calculado, a partir da fórmula:

$$
V_{B}=D \cdot S \cdot P r \cdot D a\left(P s_{C C}-P s_{a j}\right) / 100
$$

onde:

$$
\begin{aligned}
V_{B}= & \text { volume de àgua necessário em litros } \\
P s_{C C}= & \text { umidade do solo à capacidade de campo em } \\
& \% \text { de peso } \\
P s_{a i}= & \text { umidade do solo antes da irrigação em } \% \\
& \text { de peso }
\end{aligned}
$$

A área de cada gotejador é de $2,70 \mathrm{~m}^{2}(1,00 \times$ $2,70 \mathrm{~m})$ mas, para efeito de cálculo de irrigação, foi conside 
rado $50 \%$ desta ārea, isto é, $1,35 \mathrm{~m}^{2}$ em virtude do caminhamen to lateral da àgua estar em torno de $0,65 \mathrm{~m}$.

A profundidade efetiva do sistema radicular foi de $0,40 \mathrm{~m}$.

$$
\begin{aligned}
& \text { Para aplicação na fórmula, os dados foram: } \\
& \text { D.S. }=1,35 \mathrm{~m}^{2} \\
& \operatorname{Pr}=0,40 \mathrm{~m} \\
& \mathrm{Da}=1,42 \mathrm{~g} \cdot \mathrm{cm}^{-3} \\
& P S_{C C}=24,39 \% \\
& \text { Ps } \text { a }_{i}=15,92 \% \text { (considerando-se a umidade } \\
& \text { no PMP). } \\
& V_{B}=0,065 \mathrm{~m}^{3} \text { correspondendo a uma lâmina de } \\
& 48 \mathrm{~mm} \text { de àgua. }
\end{aligned}
$$

Cada parcela tinha 60 gotejadores, com uma vazão média de 4 l/hora $(3 \mathrm{~mm} / \mathrm{h})$ à pressão de $10 \mathrm{~m} . c . a$.

Após este período de uniformização do bulbo mo Ihado, a dotação de água para os diversos tratamentos passou a ser a seguinte:

$$
\begin{aligned}
& \text { Tratamento } 1-1,0 . \text { ECA } \\
& \text { Tratamento } 2-0,8 . \text { ECA } \\
& \text { Tratamento } 3-0,6 . \text { ECA } \\
& \text { Tratamento } 4-0,0 . \text { ECA }
\end{aligned}
$$




\subsubsection{Adubação da soca e ressoca}

Em 15 de agosto de 1977 teve início a colheita da cana planta e o ciclo da cana soca. Para a adubação da cana soca e ressoca empregou-se $60 \mathrm{~kg} / \mathrm{ha}$ de nitrogēnio e $60 \mathrm{~kg} /$ ha de $K_{2} \mathrm{O}$, tendo-se como fontes destes nutrientes o sulfatode amōnio, uréia e o cloreto de potássio. A adubação fosfatada foi realizada no plantio. A aplicação do adubo foi feita pela àgua de irrigação nas parcelas irrigadas, e nas não irrigadas (testemunhas) a aplicação foi manual.

o adubo era dissolvido na ägua no prōprio inje tor de adubo, e a quantidade apticada era controlada por meio de vāivulas.

3.2.5. Análise dos dados

\subsubsection{Crescimento da cana}

A medição do crescimento foi tomada na prime ra aurícula visível (altura da inserção da primeira folha) me dida em 3 canas de cada tratamento previamente marcadas ao acaso nas 5 repetições, totalizando 60 plantas medidas semanalmente. Ao lado de cada planta, um piquete numerado, servia de base para esta medição. As medições iniciaram-se no n. dia 01/10/77 para a cana soca e 04/09/78 para a cana ressoca até o dja 28/06/78 para a soca e 16/07/79 para a ressoca. 
3.2.5.2. Relações entre o desenvolvimento vegetativo da soca e ressoca e condições climáticas

A - Caracterização do desenvolvimento vegetativo

A velocidade de crescimento é afetada pela tem peratura do meio ambiente, havendo para cada espécie uma temperatura limite, abaixo da qual o crescimento não é significa tivo. Para a cana-de-açūcar estā prōximo de 200 c, como consideram FAUCONNIER e BASSEREAU (1970).

Baseado nestes fatos, desenvolveu-se o conceito de graus dia, que, para Robertson, citado por VILLA NOVA et a zii (1972), representa a diferença diāria entre temperatura média do ambiente e a temperatura considerada limite para a espēcie.

As alturas de cada tratamento, constituiram-se da altura média geral de trés plantas de cada repetição (5 re petições $\times 3$ plantas/repetição = 15 plantas $)$.

Tomou-se um intervalo de crescimento de 4 se manas, obtendo-se a variação de altura do período $(\Delta H)$ assim como o valor absoluto $(H=\Sigma \Delta H)$ para cada tratamento. No pre sente trabalho foi feita uma caracterização de função de clima idéntica aquela proposta por VILLA NOVA (1982)*, denominada de "Grau dia corrigido para Fotoperiodo" - (GD).

* Comunicação pessoal 
B - Caracterização da "função de clima"

Os dados de $\Delta H$ obtidos, foram correlacionados, com uma função de clima, idēntica aquela proposta por VILLA NoVA (1982)*, denominada de "Grau dia Corrigido para Fotoperĩodo" (GD).

Para calcular GD, foram utilizadas as expres-

sões:

$$
\mathrm{GD}_{T}=\frac{(n \overline{G D})^{n f / n i+1}}{n f / n i+1} \cdots \ldots \ldots \ldots \ldots \ldots
$$

onde:

$$
\begin{aligned}
& \mathrm{GD}_{T}=\text { graus dias corrigidos totais } \\
& \bar{G} \bar{D}=\text { valor do graus-dia, média do intervalo } \\
& n=\text { nümero de dias do intervalo } \\
& n_{f}=\text { valor do fotoperiodo no fim do intervalo (horas) } \\
& n_{i}=\text { valor do fotoperiodo no inicio do intervalo (horas) }
\end{aligned}
$$

o valor do grau dia médio do intervalo, foi de terminado pelas expressões:

$$
\begin{aligned}
& \overline{G D}=\frac{(\bar{T}-t b)^{2}}{2(\bar{T}-\bar{t})} \quad \ldots \ldots \ldots \ldots \ldots \ldots \ldots . \\
& \overline{G D}=\left(\frac{\bar{T}-\bar{t}}{2}\right)+(\bar{t}-t b) \quad \ldots \ldots \ldots \ldots \ldots \\
& \text { para } t b<t
\end{aligned}
$$


onde:

$\bar{T}=$ média das temperaturas māximas do intervalo

$E=$ média das temperaturas minimas do intervalo

tb = temperatura minima para o desenvolvimento vegetativo apreciável (temperatura base), tomada no caso como $18^{\circ}$ $c\left(t b=18^{\circ} \mathrm{C}\right)$

C - Relaçōes de dependẹncia entre $H$ e $G D_{T}$

Com o objetivo de caracterizar a dependéncia do desenvolvimento vegetativo $(\Delta H)$ com relação ao clima carac terizado pela função de clima jā descrita $\left(G D_{T}\right)$, um estudo de regressão linear da interação $\Delta H \times G_{T}$, foi conduzido para ca da tratamento, tanto para soca como para ressoca.

3.2.5.3. Produtividade e número de colmos

Na colheita da cana de cada parcela fez-se fei xes de 10 canas para pesagem e contagem dos colmos. Com auxí lio de um dinamómetro montado em trator fez-se as pesagens.

\subsubsection{Anālise estatî́stica}

A - Anālise da Variāncia

Os resultados obtidos para produtividade e nūmero de colmos foram analisados segundo o delineamento de blo cos casualizados, sendo o seguinte o esquema da anālise de va 
riāncia.

\begin{tabular}{|c|c|c|c|c|}
\hline Causas da Variacão & G.L. & S.Q. & Q.M. & H \\
\hline Tratamentos & $I-1$ & & & \\
\hline B $10 \mathrm{cos}$ & $r-1$ & & & \\
\hline Resíduo & $I(I-1)$ & & & \\
\hline Total & $r I-1$ & & & \\
\hline
\end{tabular}

\footnotetext{
onde: $I=$ nūmero de tratamento $\mathrm{e}$, $r=$ nümero de blocos.
}

Os resultados obtidos para crescimento foram analisados segundo o esquema "Split-plot" em blocos casualiza clos, sendo o seguinte o esquema da anāi ise da variáncia. 


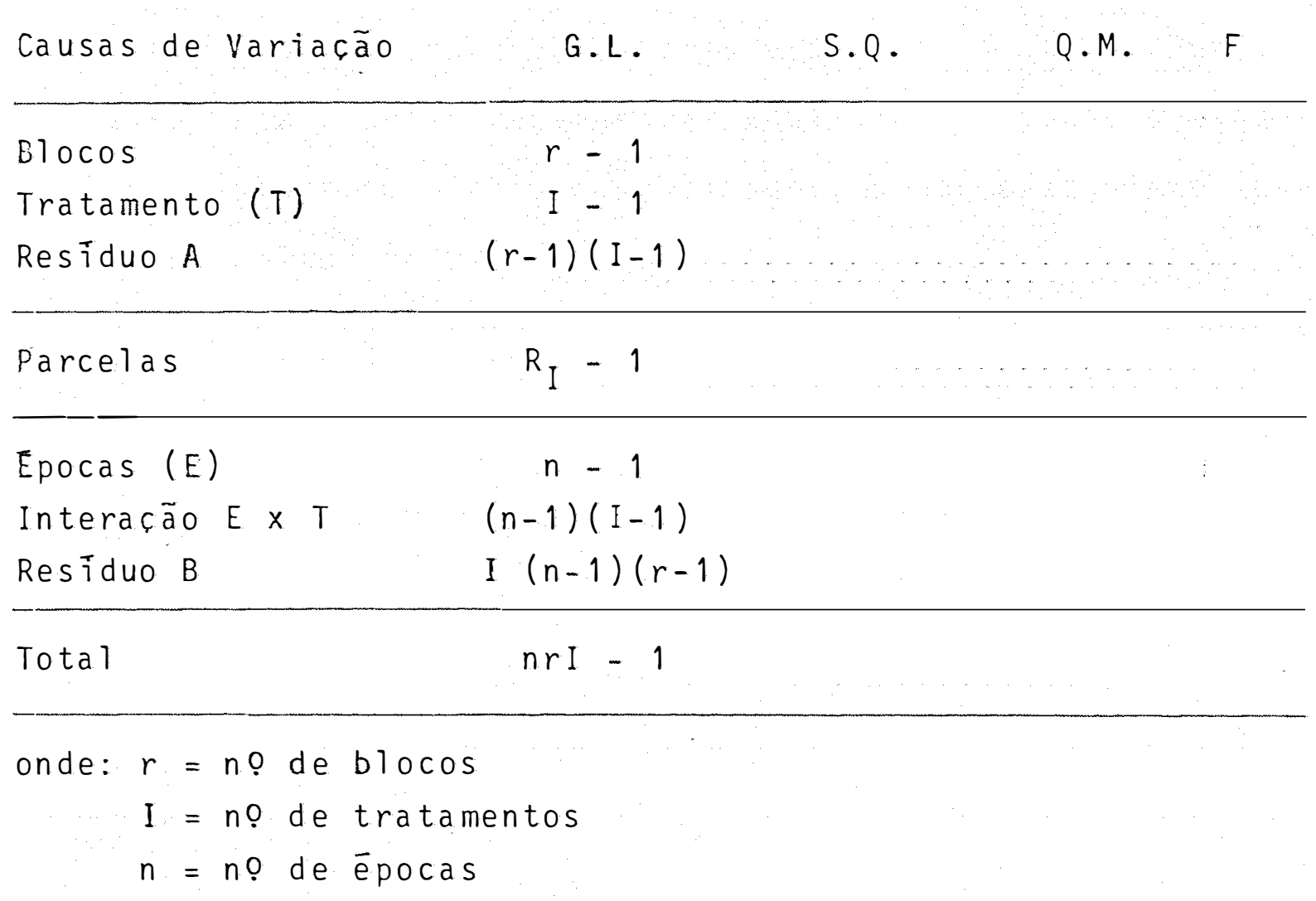

0 teste $F$ para Tratamentos dentro da Epoca é feito utilizando-se o Quadrado Médio do Resíduo calculado da seguinte forma:

$$
\text { QM Res. Médio }=\frac{(n-1) \text { Q.M. Residuo }}{n} \frac{B+Q \cdot M \text {. Resíduo } A}{n}
$$

0 número de graus de liberdade para esse Resĩduo Médio é calculado pela fórmula de SATTERTHWAITE (1946) dada por:

$$
n^{\prime}=\frac{\text { Q.M. Residuo } A+(n-1) \text { Q.M. Residuo B }}{\frac{(Q \cdot M \cdot \operatorname{Residuo~} A)^{2}}{(r-1)(I-1)}+\frac{(n-1)^{2}(Q \cdot M \cdot \operatorname{Residuo~} B)^{2}}{I(n-1)(r-1)}}
$$


B - Comparação de médias

A comparação das médias de Tratamentos dentro de Epocas e Tratamentos foi feita utilizando-se o teste de Dunnett que segundo ele, testa a significāncia entre as médias dos tratamentos e a média da testemunha. E, portanto, um teste especifico para os casos em que se quer comparar diversos tratamentos com uma testemunha. Calcula-se, inicialmente a estatistica:

$$
t^{\prime}=\frac{\bar{m}_{t}-\hat{m}_{0}}{\sqrt{\left(\frac{l}{n_{t}}+\frac{1}{n_{0}}\right) \text { QMRes }}}
$$

onde: $\overline{\mathrm{m}}_{t}=$ média do tratamento

$\bar{m}_{0}=$ média da testemunha

$n_{t}=$ nọ de repetições com que foi calculada a média dos tratamentos

$n_{0}=$ nọ de repetições com que foi calculada a média da testemunha.

A comparação das médias de Tratamentos dentro de Epocas foi feita utilizando-se o teste de Tukey. Para tan to calcula-se a estatistica: 


$$
\Delta .=q \frac{\sqrt{\text { QMRes }}}{\sqrt{r}}
$$

onde $=$

$$
\begin{aligned}
q= & \text { valor tabelado ao nīvel de } 5 \% \text { ou } 1 \% \text { de pro } \\
& \text { babilidade } \\
r= & \text { número de repeticões do tratamento. }
\end{aligned}
$$

Todos os contrastes de duas médias que forem, em valor absoluto, maior que $\Delta$, serão significativos a um nível a de probabilidade e diz-se que as mēdias diferem entre si. 


\section{RESULTADOS E DISCUSSÃO}

os dados coletados na área experimental foram analisados permitindo obter os seguintes resultados:

4.1. Volume de ägua aplicado.

A irrigação de uniformização do bulbo molhado iniciou-se em agosto de 1977 e de 1978, para a cana soca e ressoca, respectivamente.

Todas as parcelas dos tratamentos A, B e C, re ceberam a mesma quantidade de āgua, calculada, sagundo JAIME (1973) para a profundidade de 0,40 m.

A partir desta data iniciou-se a diferenciação entre as dotaçōes de àgua, pré-estabelecidas, e as leituras do crescimento.

As Tabelas 7 e 8 mostram o volume de àgua rece 
47.

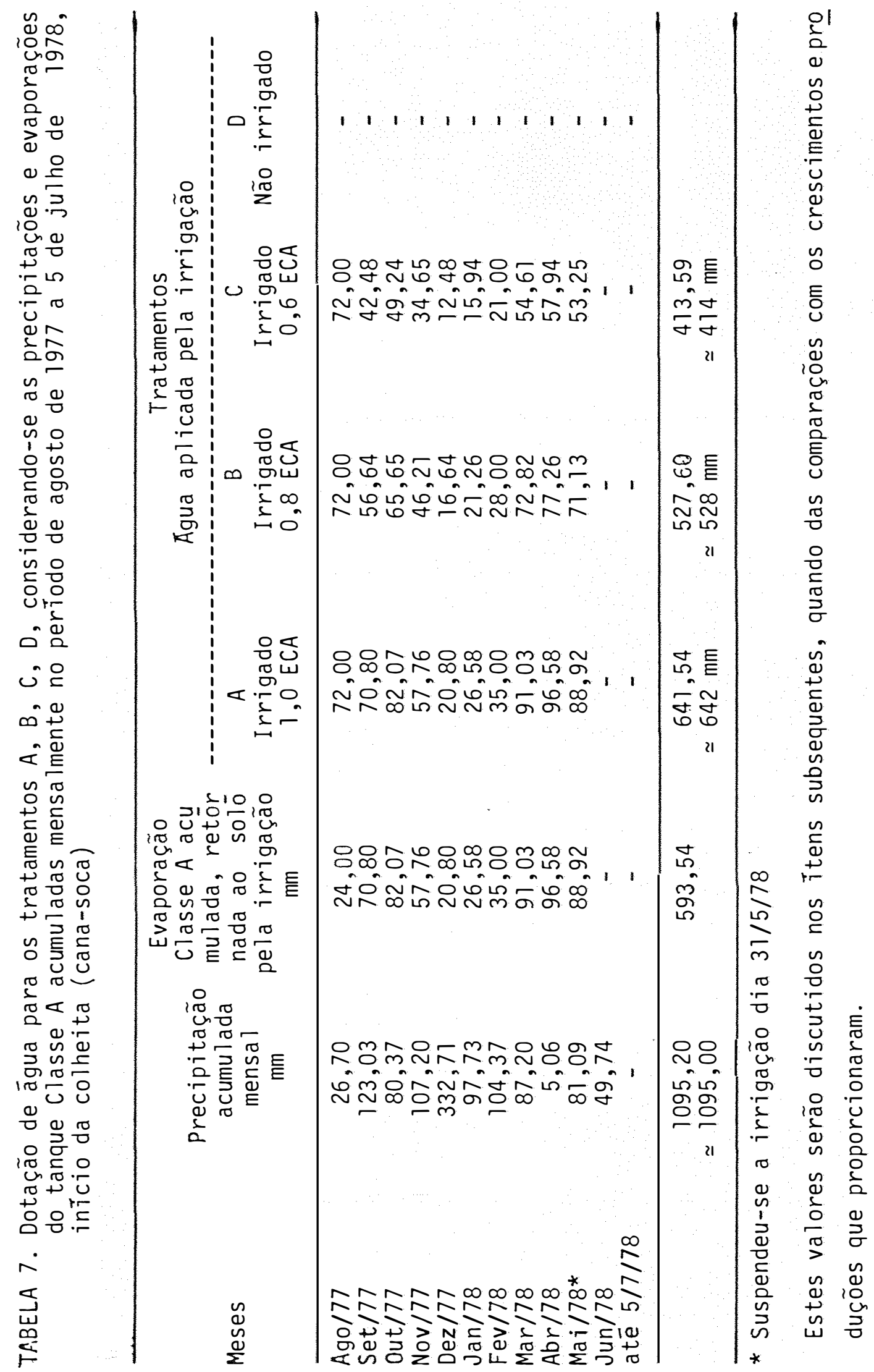




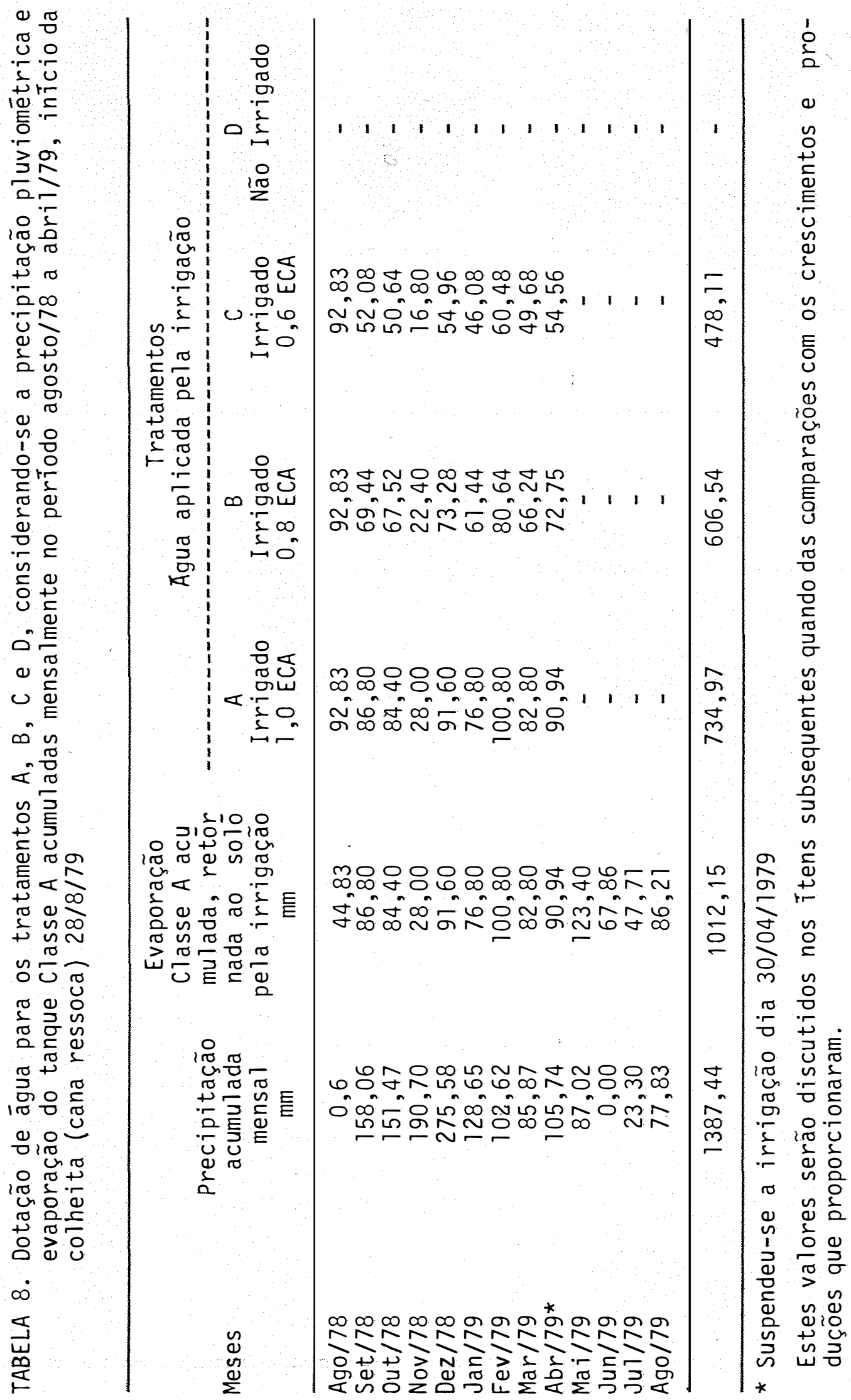


bido pelos tratamentos nos períodos considerados para cana so ca (agosto de 1977 a 5 de julho de 1978) e para cana ressoca (agosto de 1978 a 28 de agosto de 1979).

\subsection{Crescimento}

4.2.1. Anālise estatistica

Para se verificar o comportamento da cultura submetida aos vārios tratamentos de irrigação foi determinado, semanalmente, o crescimento do colmo em $\mathrm{cm}$, tomado na pri meira aurícula visível.

Os dados de crescimento se encontram nas Tabelas 9 e 10 e foram analisados em esquema "Split-plot" em blocos casualizados, e os resultados estão nas Tabelas 11 e 12.

0 teste $F$ para tratamentos não foi significati vo ao nivel de $5 \%$ de probabilidade.

Observando-se a Figura 7 (cana soca) verifica- se que até outubro de 1977 e nos meses de abril, maio e junho de 1978, término do experimento, o crescimento da primeira aurícula visivel foi pequeno, não se registrando diferencas significativas entre os tratamentos. Na Figura 8 (cana ressoca) verifica-se o mesmo inicialmente, até outubro de 1978, não ocorrendo nos meses finais, pois que o experimento 
:

ఎ D

00000 0 0000

00000

0.000

$\approx$

$\stackrel{\sim}{m} \prod_{m}^{\infty} \underset{m}{\infty} \underset{m}{\sim}$

ก

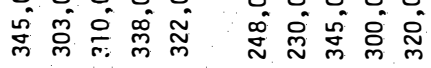

in

$0: 0$ : 웅

0.000

0000.

00000

50

0.0 .000 .000

㝦

$\stackrel{\infty}{\infty} \stackrel{\infty}{\infty} \underset{\infty}{\infty} \stackrel{\infty}{\infty}$

0.0 .0$.

0.000

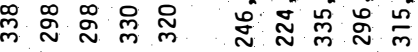

$0.000 \quad 00000$

0000

0.0 .0

$\stackrel{\Sigma}{\curvearrowright}$

羟 $\frac{\mathfrak{m}}{0}$

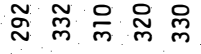

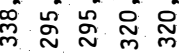

$\stackrel{\sim}{\sim} \underset{\sim}{\sim} \stackrel{\sim}{N} \frac{m}{m}$

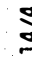

0.0 .0 .000 .00

00000

00000

$\stackrel{2}{\Sigma}$

o 0.0 .000000

怘 首

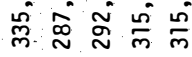

点

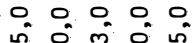

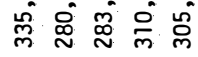

0.0 .0 .0

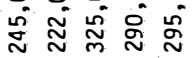

$\frac{m}{2}$

$00000 \quad 00000$

峦 $\frac{0}{m} \frac{0}{m} \frac{\infty}{m}$

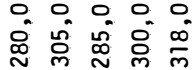

0.0 .0$.

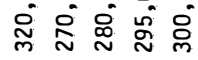

0.0 .0 .0

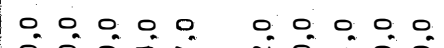

$\stackrel{m}{m}$

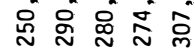

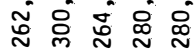

o. 0.0 .0

స స స 용 న

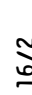

0.0 .0 .0$.

0.0 .0 .0 .0

m $\stackrel{\infty}{\sim} \stackrel{\infty}{\sim} \stackrel{\infty}{\sim}$

0.0 .0 .0

0.00 .0

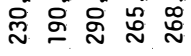

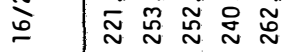

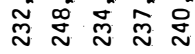

ผ $\underset{\sim}{\sim} \stackrel{\sim}{\sim}$

0.0 .0 .0

$\frac{2}{2}$

0.000.

0.000.

0.0 .00

$\stackrel{\infty}{\infty} \stackrel{\sim}{\sim} \stackrel{\sim}{\sim}$

$\frac{2}{2}$

0.0 .0 .000 .000

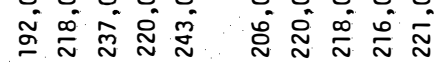

0.0 .0 .0

$\stackrel{m}{\sim} \stackrel{n}{\sim} \stackrel{m}{\sim} \stackrel{m}{\infty}$

ㅇ․ 0.0

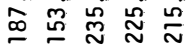

స్

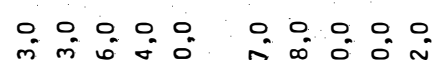

$\therefore \circ 0.0$

00.00

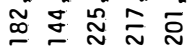

$\stackrel{\bar{\infty}}{\infty}$

ㅇ. 0.0 .000000 ก-1

00000

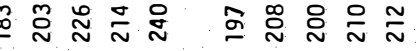

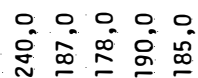

$\stackrel{\circ}{=}$ 옹 $\approx$ 용

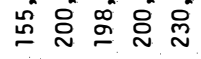

मू ฏ

-

0 ㅇ․ 00

$\stackrel{\infty}{\Sigma}$

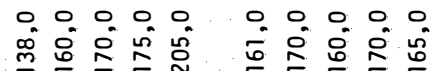

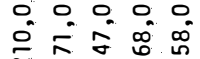

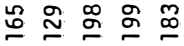

$\frac{2}{5}$

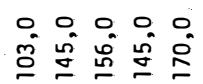

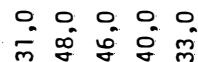

00000

000.0

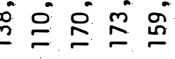

亲害咅兽

0000

0.0 .0

$\cong$

0.000

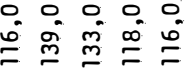

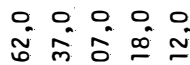

$\Xi \infty \underset{\Xi}{\infty} \stackrel{\infty}{\underline{\Xi}}$

ะ

กิ

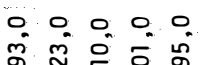

0.000

mi n

0.000 .0

รें

0.0 .0 .0

$\equiv$

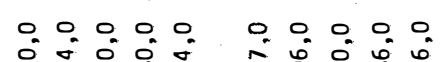

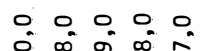

을

ऊू

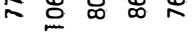

ำ

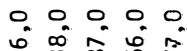

$\equiv$

m 0

$\begin{array}{lllll}2 & 0 & 0 & 0 & 0 \\ 0 & 0 & 0 & 0 & 0\end{array}$

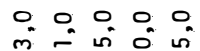

000.0

$\stackrel{ }{\frac{1}{2}}$

0.0 .0 .0 .0 .0 .00

क ज

0.0 .0 .0

ํำ

을

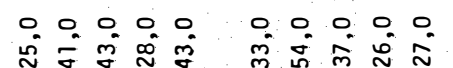

o o o o

iी

ชั

ก

0.0 .0 .000 .00

$\stackrel{\circ}{m}$

ก ڤ

$\approx$ i

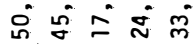

00000

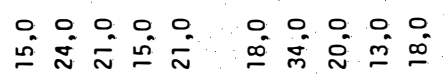

ㅇ. ㅇ․ 0.0

ஸ

$\stackrel{ }{\infty}$

o 000

0.0 .00

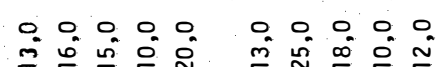

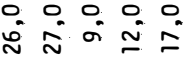

- 0000

岕

음

0.0 .0

กั่

0000

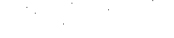
$-\infty m \infty$

$-\sim m \sigma n$ 


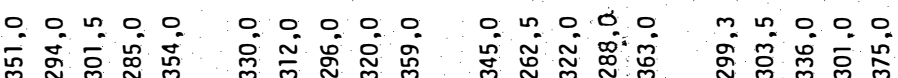
0.0 n 00000000000000000

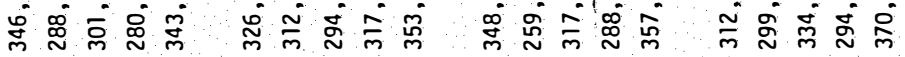

0.0 .0 . n. 0

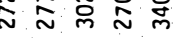

0.0 .0

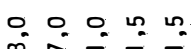
0.0 .0 .0 ㄷ. 0.0 .0 . 罚交交票

กำ ลั ฐ

造管管

0.0 .0 .0

0.0 .0 .0 .0$.

ㅇ․ 0.0 .

o m o o 0 .

O 00.00.

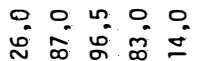

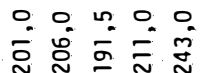

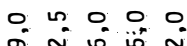

స్心 in $\infty 000$

- 0 in 0

O n 0.0 .0

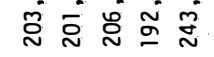
ㅇ. 0.0 .0 呦怘

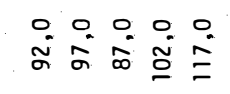

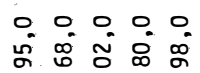

0.0000

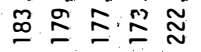

ㅇ․ no. 0.0 0.0000

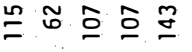

0.0 .0$.

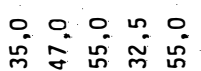

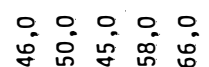

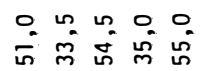

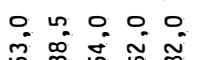

$\therefore: 0.0 .0$. 舟落

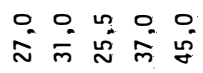

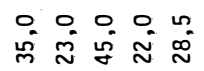

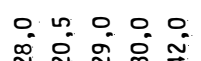
n. 0.00

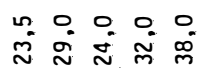

n 0 . n. 0.0 n. 0.0 .0$. -

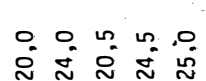
లె స్లి స 六 $\approx \stackrel{\infty}{\sim}$

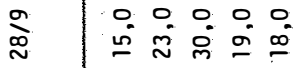
i

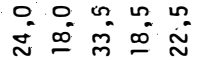

o. 0.0 .0 .

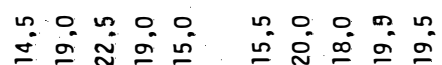

ㅇ. ㄴ. ㅇ․ ㄴ. n. $\dot{\sim} \approx \dot{\sim} \sim$

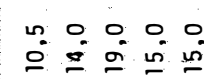

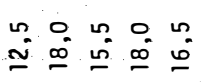
$\sim \div \div$

0.0 .00

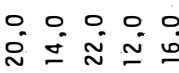

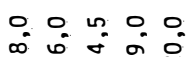

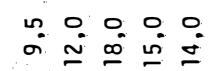

$\infty$
$\infty$
$\infty$
$=$

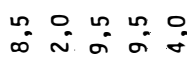

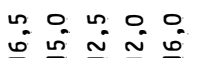


TABELA 11. Análise de variância dos dados de crescimento do colmo, em esquema "Split-Plot". Cana soca

Causas de variação

G.L.

Q.M. e significância do teste $F$

Blocos

Tratamentos

Residuo
G.L.

$\begin{array}{rr}4 & 4587.00 \mathrm{n.s} . \\ 3 & 16552.59 \mathrm{n.s} . \\ 12 & 9966.80\end{array}$

\begin{tabular}{lrr}
\hline Parcelas & 19 & \\
\hline Epocas (E) & 24 & $256984.46 \star *$ \\
Int. T X E & 72 & 174.14 n.s. \\
Residuo (B) & 384 & 142.31
\end{tabular}

Total

499

C.V. parcelas - $54.21 \%$

C.V. subparcelas $-6.48 \%$

$$
\Delta=37,50
$$

Médias de tratamentos:

$$
\begin{aligned}
& \hat{m}_{A}=191,73 \\
& \hat{m}_{B}=189,84 \\
& \hat{m}_{C}=188,06 \\
& \tilde{m}_{D}=167,06
\end{aligned}
$$

to terminou em maio de 1979, antes das baixas temperaturas. Isto confirma as afirmacões de FAUCONNIER e BAS

SEREAU (1970) de que o crescimento é consideravelmente aumenta 
do, a medida que a temperatura média se eleva acima de 200 C; é assim que a elongação da cana é quatro vezes mais considerá vel a 250̣ que a 21. Yates citado por MONGELARD eNICKEL (1972) afirma que temperaturas médias abaixo de 21.50 C afetam as res postas ao crescimento da cana quando irrigada. Na presente pes quisa a temperatura esteve abaixo de 21.50 C no inicio do expe rimento (agosto) e a partir de abril de 1978 até a colheita em julho para a cana soca, agosto, setembro de 78 para a cana ressoca.

TABELA 12. Anālise de variância dos dados de crescimento do colmo em esquema "Split-Plot". Cana ressoca

\begin{tabular}{lcc}
\hline Causas de variação & G.L. & Q.M. e significância do teste F \\
\hline Blocos & 4 & $16170.81 \mathrm{n} . \mathrm{s}$. \\
Tratamento $(T)$ & 3 & $1508.71 \mathrm{n} . \mathrm{s}$. \\
Resĩduos & 12 & 2367.45 \\
\hline Parcela & 19 & - \\
\hline Epocas (E) & 22 & $268232.38 * \star$ \\
Interação A* T & 66 & $35.92 \mathrm{n.s}$. \\
Resĩduos (B) & 352 & 163.66 \\
\hline Total & 459 & - \\
\hline
\end{tabular}

C.V. para parcelas - $31.601 \%$

C.V. para subparcelas - $8.308 \%$

$\Delta=19.056$

Médias de tratamentos

$\overline{\mathrm{m}}_{\mathrm{A}}=149.92$

$\overline{\mathrm{m}}_{\mathrm{B}}=158.05$

$\hat{m}_{C}=152.17$

$\overline{\mathrm{m}}_{D}=155.72$ 
54.

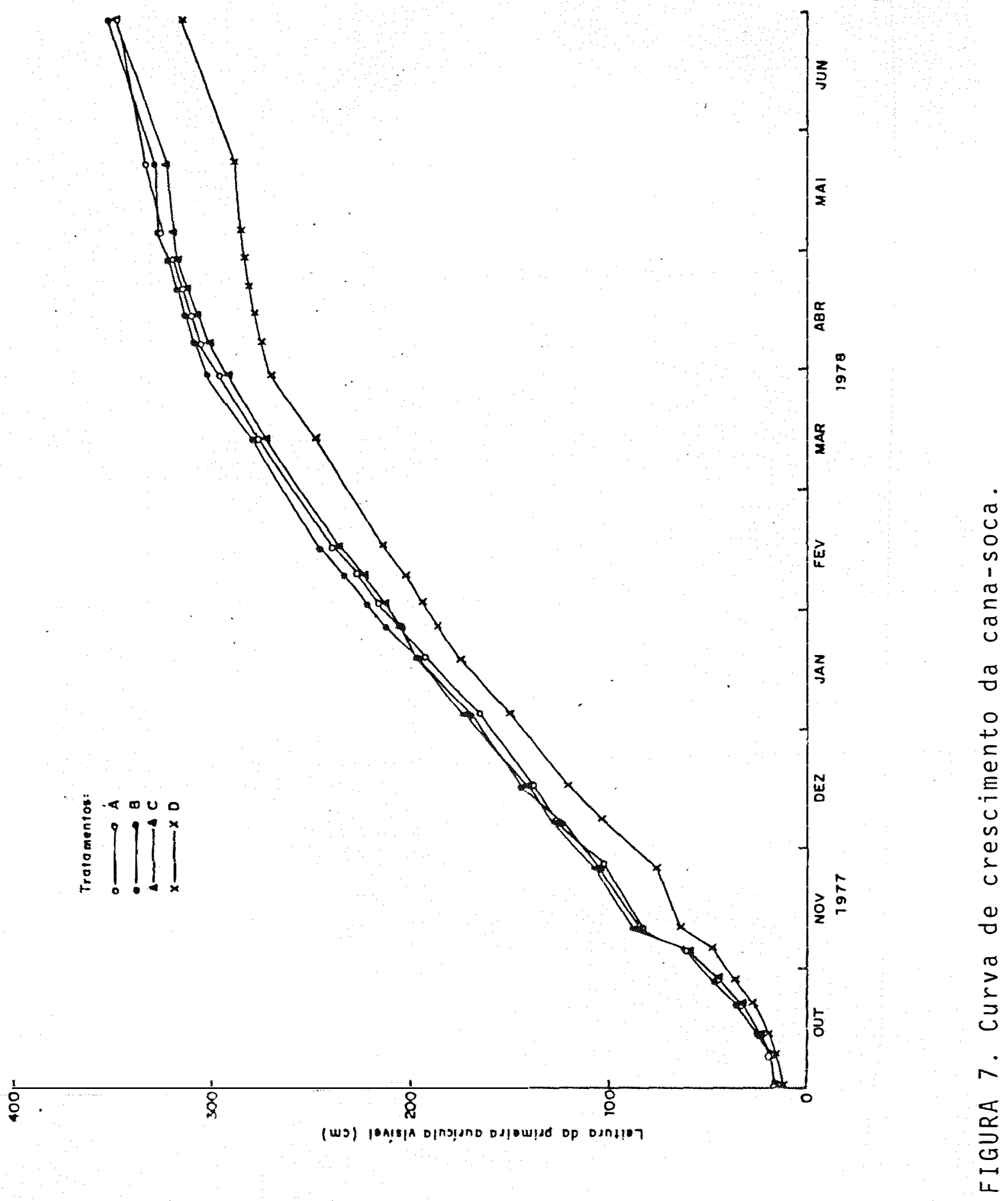




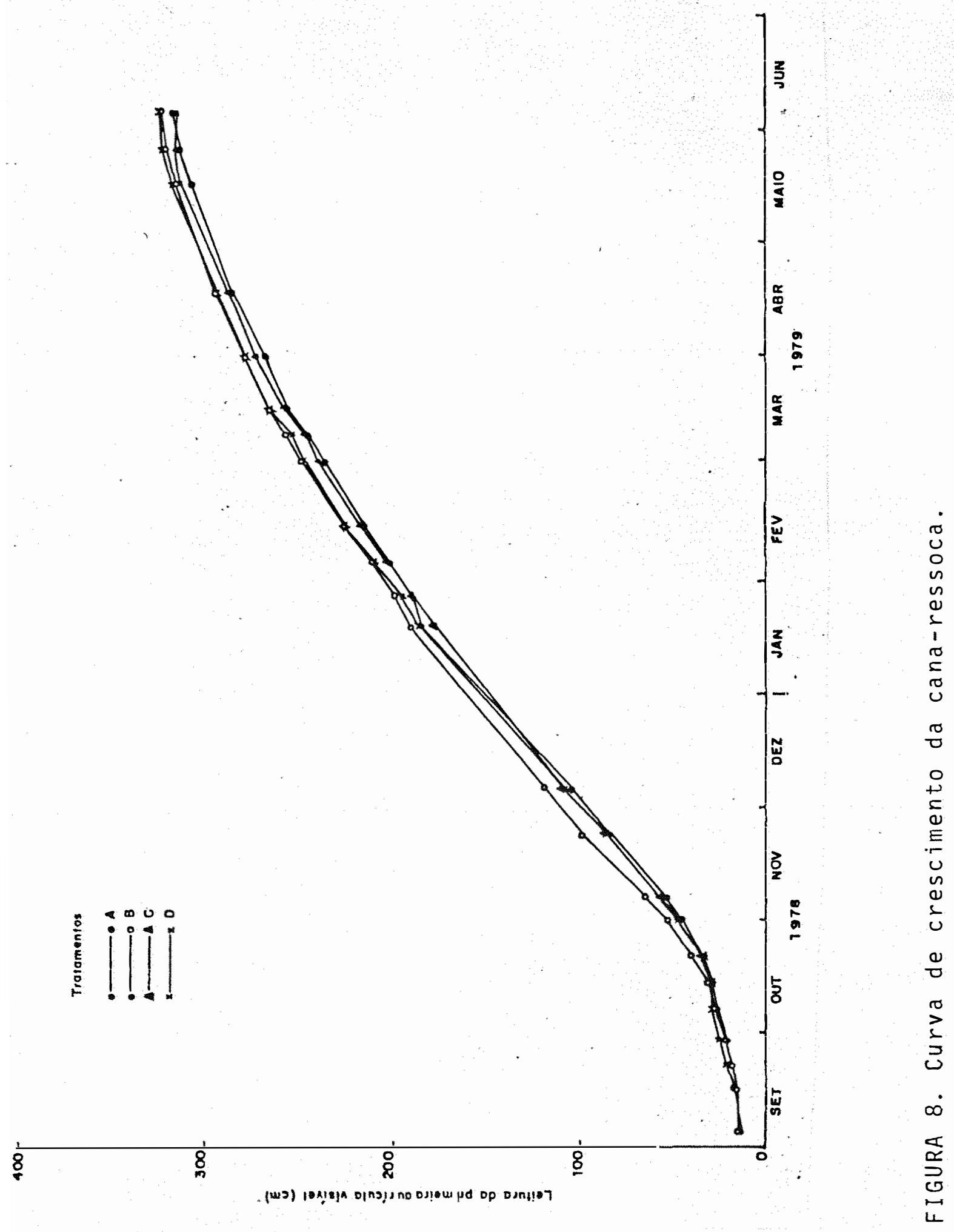


A partir de novembro de 1977 e 78 respectivamente para cana soca e ressoca, o crescimento foi muito ativo e continuo até março de 1978 na soca e maio de 1979 na ressoca, o que poderá supor que este estādio de desenvolvimento ve getativo é o mais exigente em àgua, devido as temperaturasele vadas e a coincidencia das maiores precipitações ocorreremnes se perĩodo.

SCARDUA e SOUSA (1976) também observaram que o crescimento da cana foi muito reduzido nos meses em que as tem peraturas médias estiveram abaixo de $21.50 \mathrm{C}$.

Pode-se observar na cana soca que no periodo das chuvas, outubro a março, a intensidade de crescimento entre a cana irrigada e não irrigada foi praticamente igual, e na res soca o experimento não irrigado chegou a apresentar um desenvolvimento ligeiramente superior ao irrigado no transcurso da pesquisa. A precipitação elevada na ressoca beneficiou a tes temunha, e o excesso de umidade deve ter inibido o crescimento da cana dos tratamentos irrigados.

A cana soca irrigada teve um desenvolvimentome Ihor que a ressoca, uma das justificativas para tal ocorrēncia pode ser atribuĩda ao excesso de precipitação que provocou lixiviação de nutrientes ou prejudicou o sistema radicular por excesso de umidade.

Na cana soca não houve diferenças evidentes no crescimento dos tratamentos irrigados, mas estes foram maio- 
res do que o da testemunha. A não significāncia entre os tra tamentos irrigados deve ser atribuída às precipitações elevadas, que deve ter mascarado as diferentes dotaçoes de āgua. Estes resultados diferem daqueles obtidos por SCARDUA e SOUSA (1976) e DEMETRIO (1978).

$\mathrm{Na}$ cana soca os resultados confirmam àqueles obtidos por ROBINSON (1963), SOUSA (1976b) e DEMETRIO (1978), que revelam a magnitude do crescimento como um indice indicativo do potencial de producão.

4.2.2. Relações entre desenvolvimento vegetativo da soca e res soca e condições climáticas

4.2.2.1. Caracterização do desenvolvimento vegetativo e da função de clima

Com o propósito de verificar a velocidade de crescimento em função da temperatura foi feita uma caracterização da função de clima proposta por VILLA NOVA (1982) denominada "Grau dia corrigido para Fotoperiodo". Para isto, tomou-se um intervalo de crescimento de aproximadamente 4 semanas, obtendo-se a variação de altura $(\Delta H)$, assim como o valor absoluto $(H=E \Delta H)$ para cada tratamento da soca e ressoca, cu jos valores estão nas Tabelas 13 e 14. Os valores de graus corrigidos $\left(G D_{T}\right)$ para cada intervalo e sua respectiva somatória $\left(\Sigma G D_{T}\right)$ se encontram nas mesmas Tabelas.

Atravēs de um estudo de regressão linear entre a variacão de altura $(\Delta H)$ da insercão da la aurícula vi- 


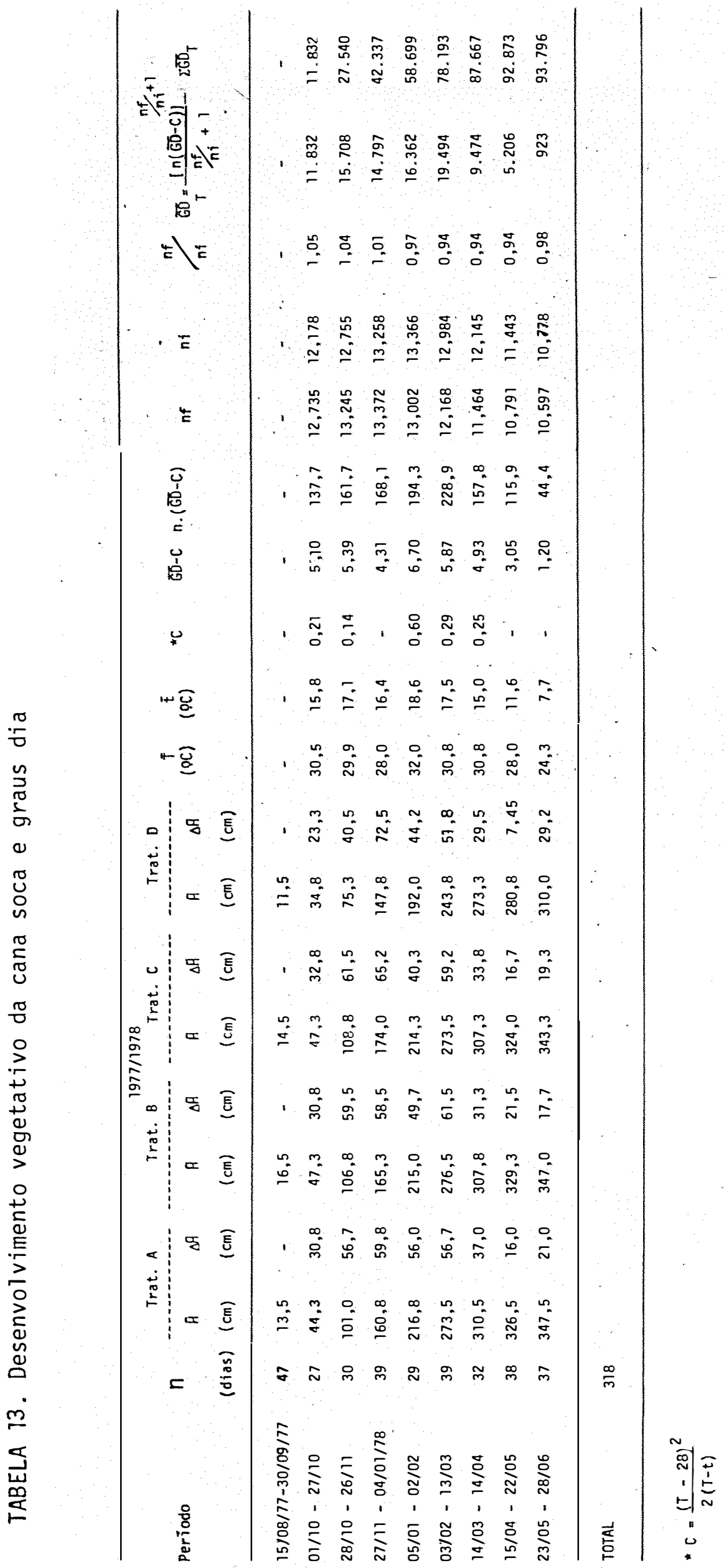




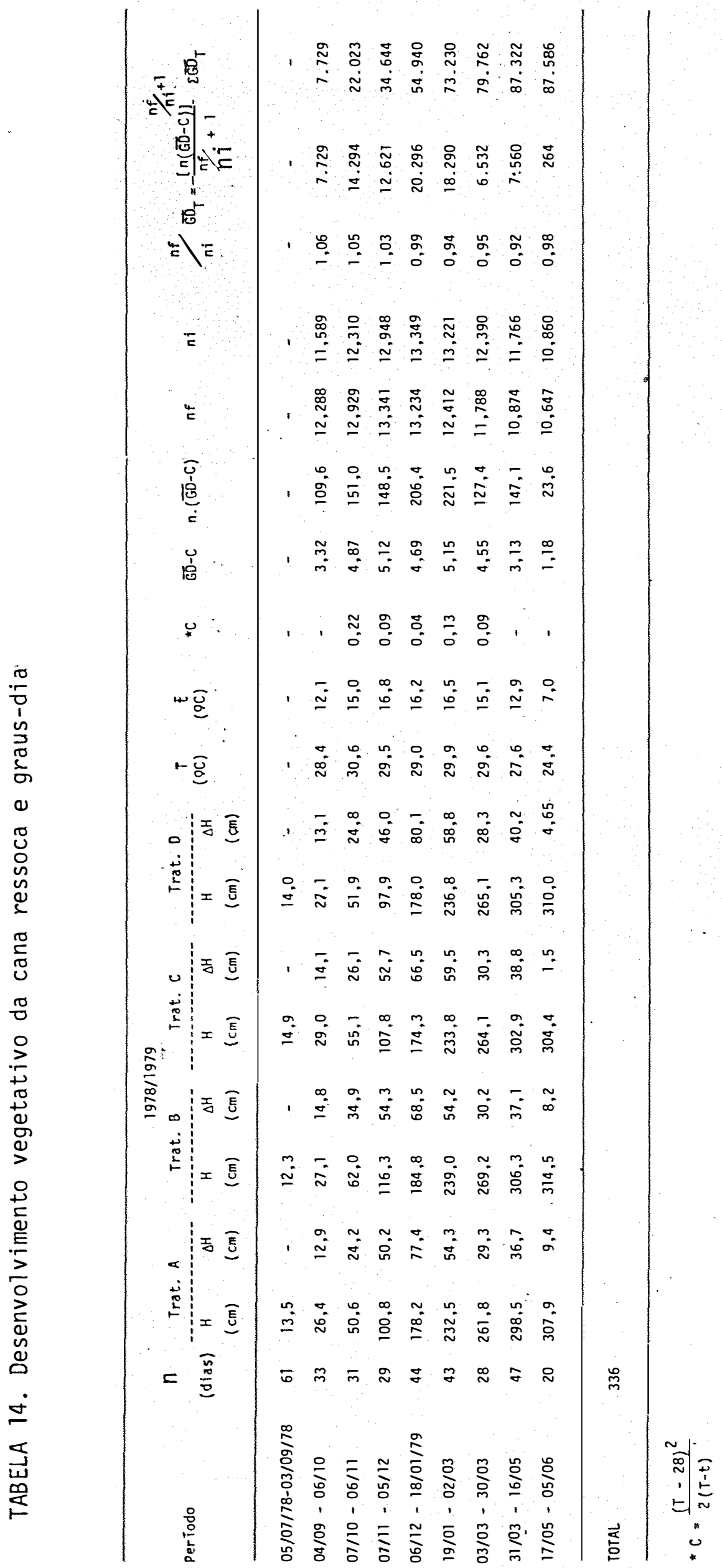


sivel e os respectivos graus dia corrigidos do intervalo $\left(G D_{T}\right)$, obtiveram-se as seguintes equaçōes conforme Tabela 15.

TABELA 15. Equações de regressão entre crescimento ( $\triangle H$ ) e graus dia acumulados, no periodo.

Cana soca

Trata-

mentos

Equações $(\Delta H)$

$r$

$r^{2}$

$\begin{array}{lllll}A & \Delta H & =11,2663+0,0026 G D_{T} & 0,9063 * * & 0,8214 \\ B & \Delta H=9,6563+0,0027 G D_{T} & 0,9307 * * & 0,8662 \\ C & \Delta H=10,6163+0,0026 G D_{T} & 0,8516 * * & 0,7252 \\ D & \Delta H=12,6848+0,0021 G_{T} & 0,6596 & 0,4351\end{array}$

Cana ressoca

Trata-

mentos

Equações $(\Delta H)$

$r$

$r^{2}$

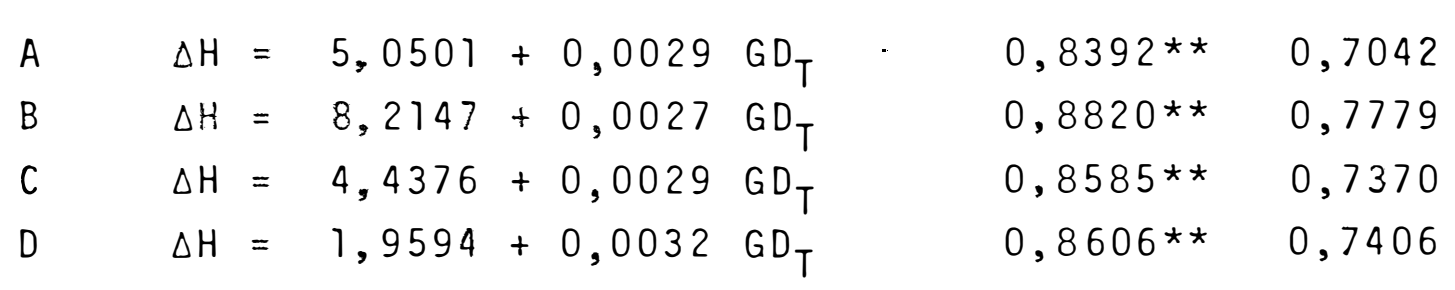

De um modo geral pode-se observar uma razóavel significāncia entre as interações $\Delta H \times G_{T}$ (significativas ao nível de $1 \%$ ), com excessão do Tratamento $D$, cana soca. Tal fa to pode ser explicado pela ocorréncia de falta d'água no periodo vegetativo. Sendo os tratamentos $A, B, C$ tanto na soca como na ressoca, irrigados, pode-se considerar excluída a influéncia da falta de chuvas no periodo. Pode-se observar tam- 
bēm que as correlações de um modo geral são ligeiramente meIhores para a cana soca, indicando, talvez, uma melhor respos ta ao clima nas condicões de 20 corte do que no 30 corte.

Convém observar que correlações para períodos de tempo menores (cerca de 15 dias) foram tentadas, não se obtendo resultados satisfatórios. Acredita-se que para perío dos de tempo relativamente pequenos os erros de medicão são porcentualmente maiores, prejudicando as correlações, e que a partir de 30 dias tais erros são minimizados.

Nas Figuras $9,10,11,12,13,14,15$ e 16, são representadas as curvas de crescimento e de graus dia corrigi dos acumulados, revelando uma aderēncia razóavel das curvas.

$\mathrm{Na}$ cana ressoca nota-se um cruzamento inicial das curvas (a curva de graus dia corrigido, superpõe-se a de crescimentol tal situação pode ser explicada pela época de corte mais prematuro da cana soca $(05 / 07 / 78)$. Em fins de agosto o desenvolvimento vegetativo é mais rāpido, condicionando um maior incremento da ārea foliar por intervalo de crescimento, determinando um melhor aproveitamento da energia disponivel, expressa pelos graus dia do perîodo.

Convém observar que repeticões deste experimen to deverão ser feitas, para que se possa consolidar tais resultados. Pretende-se com isto que uma vez bem determinadas, 


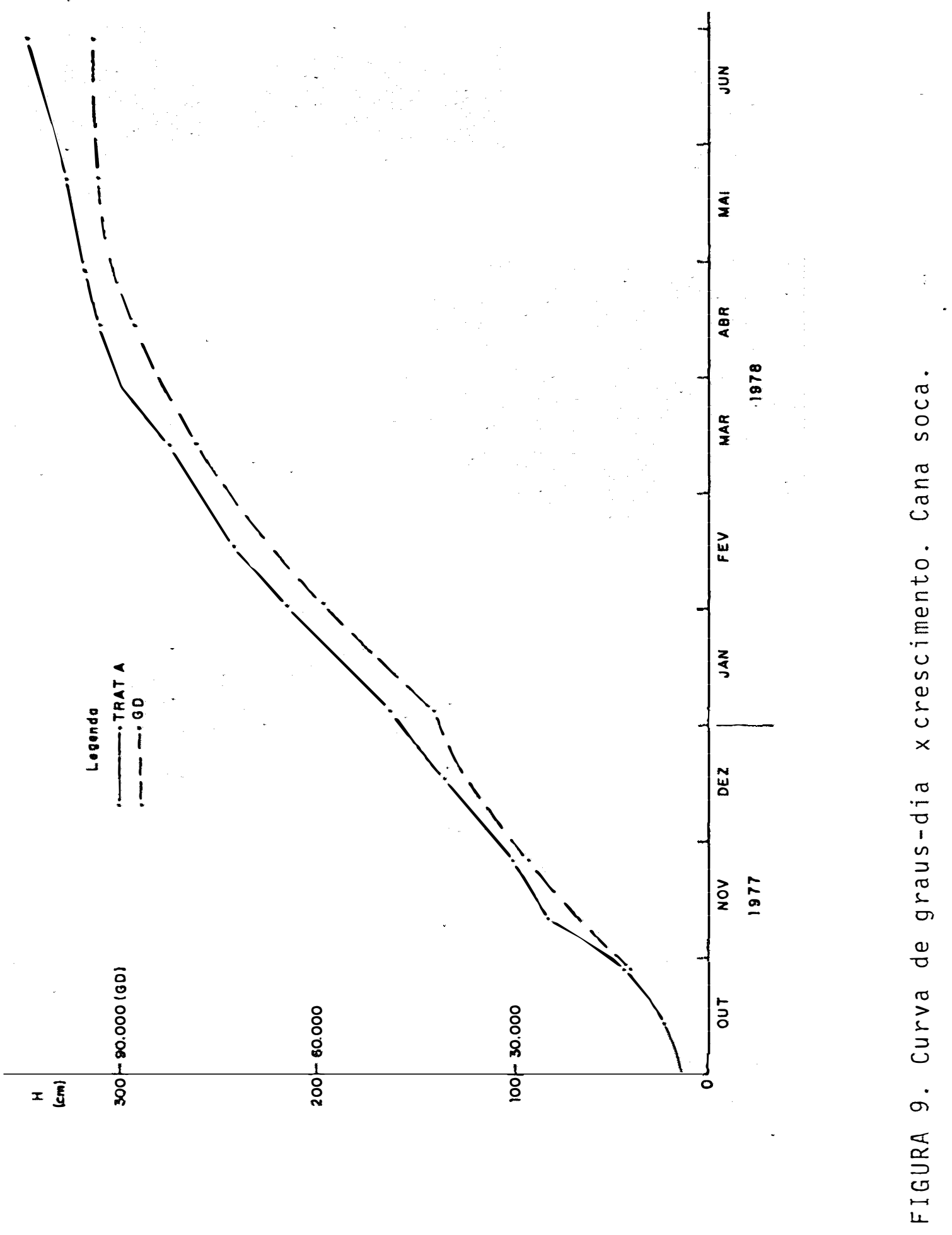




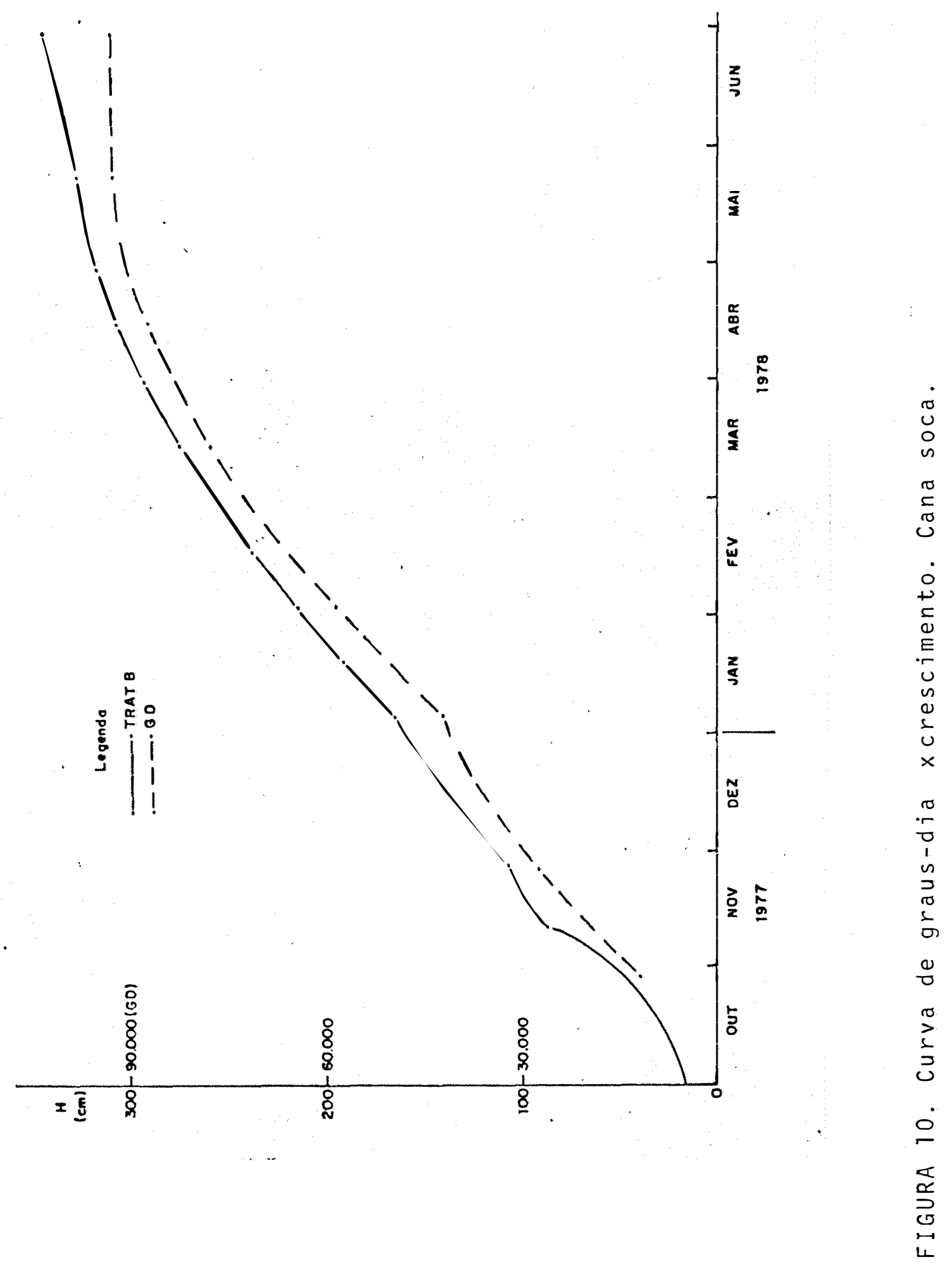


64.

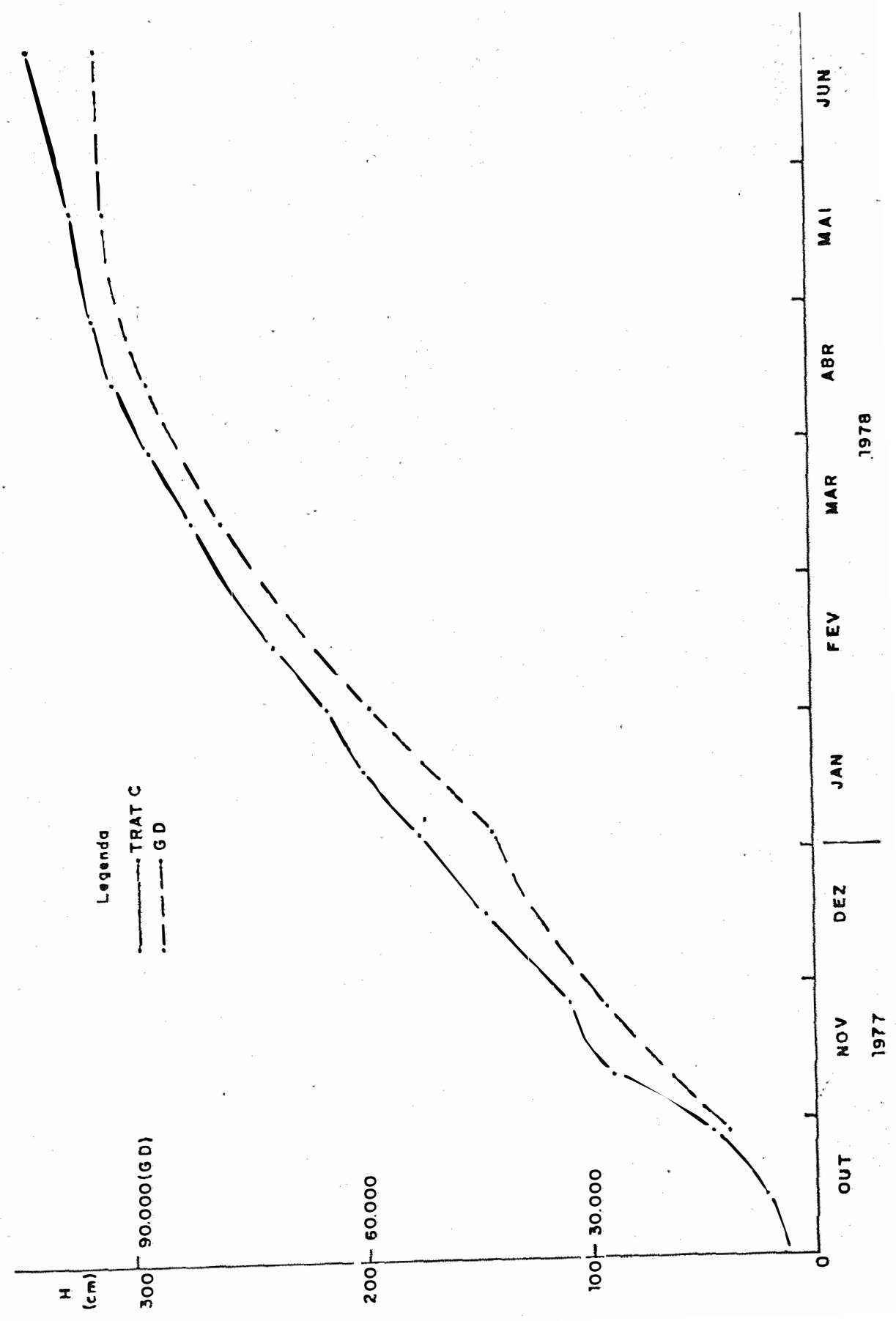

0
0
0
0
0
0
0
0
0
0
0
0
0
0
$E$
0
0
0
0
0
$x$
0
0
0
0
0
0
0
0
0
0
0
0
0
5
0
0
$\vdots$
$\vdots$
0
0
0
0
4 


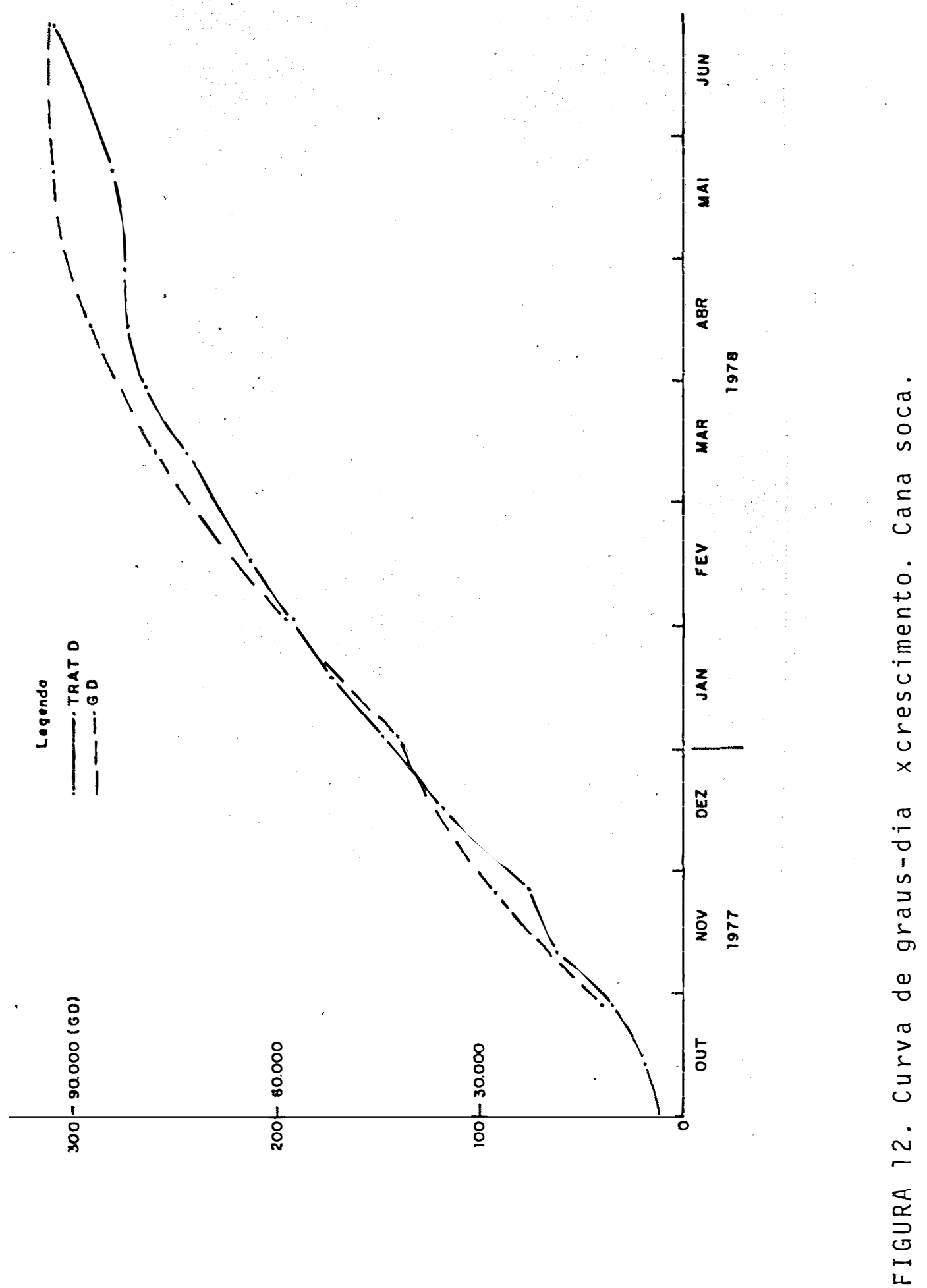




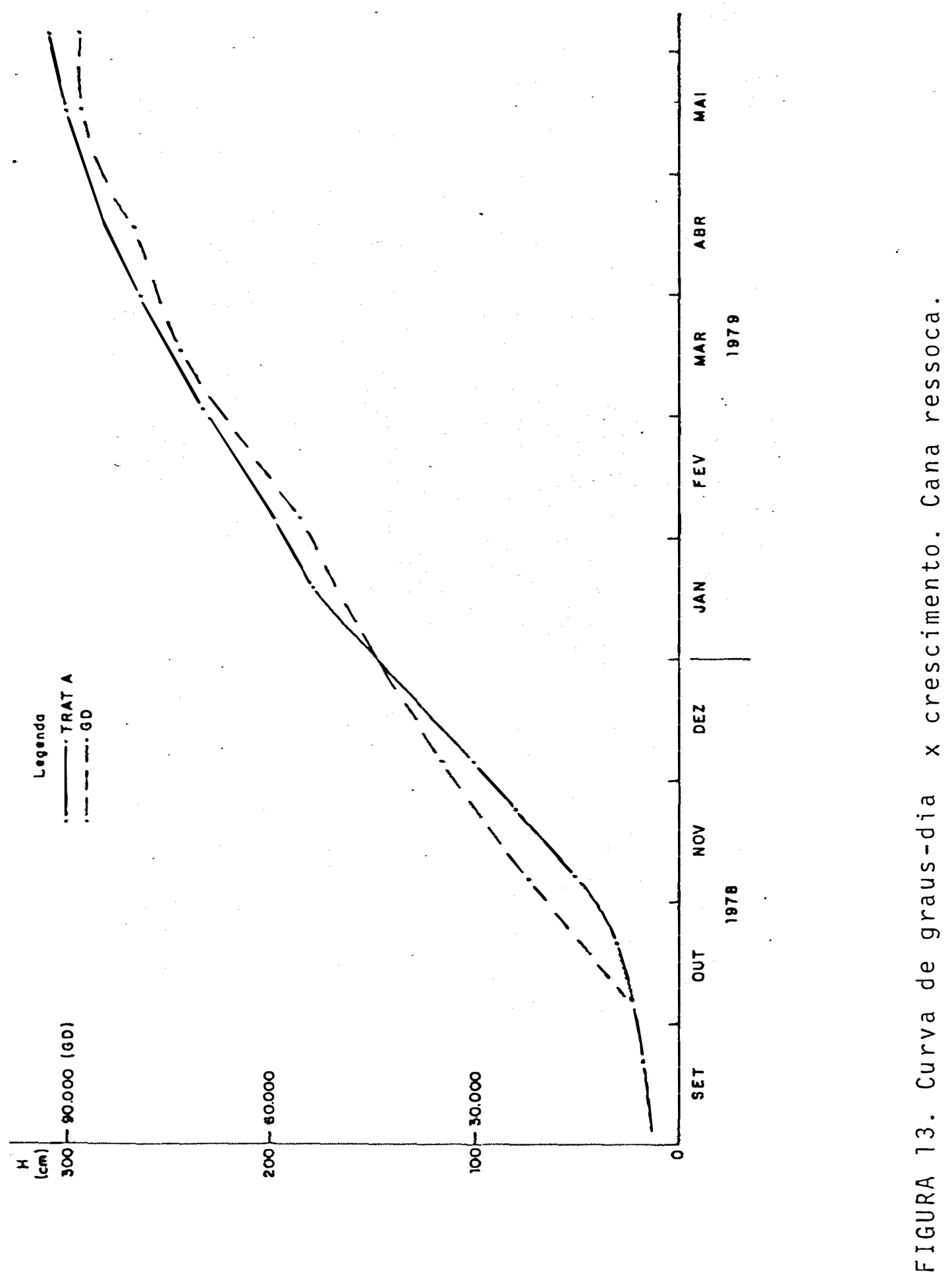


67.

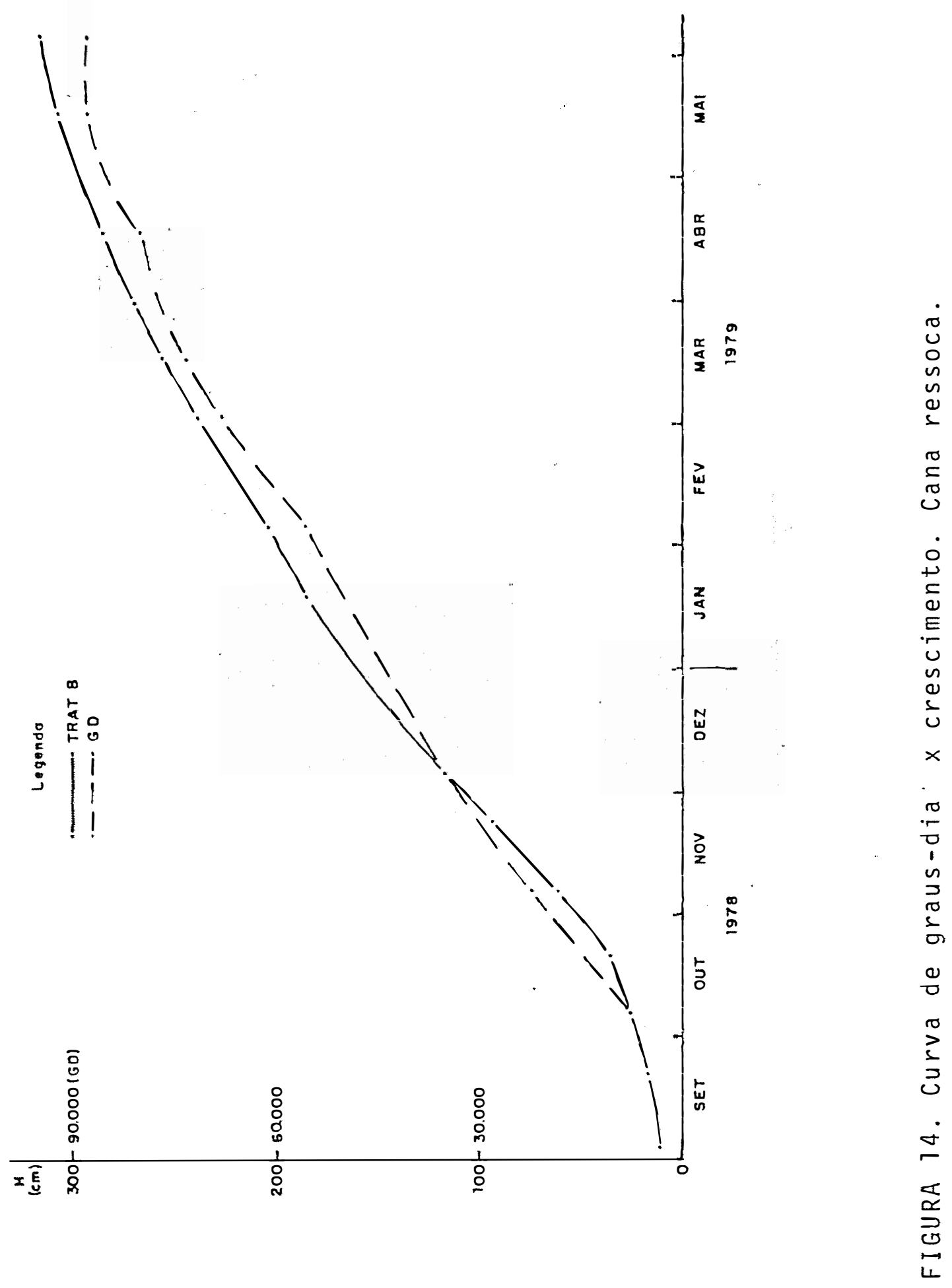


68.

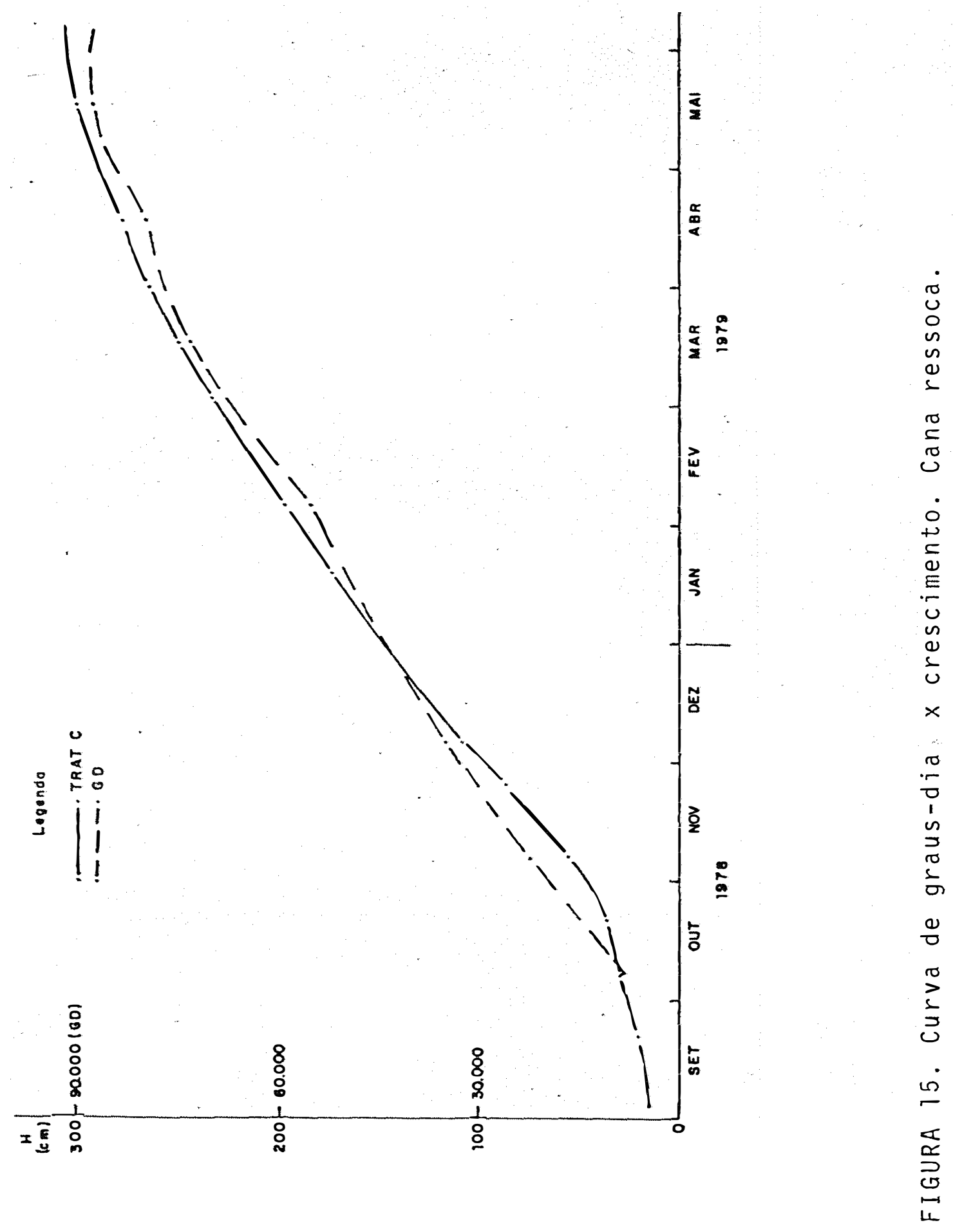




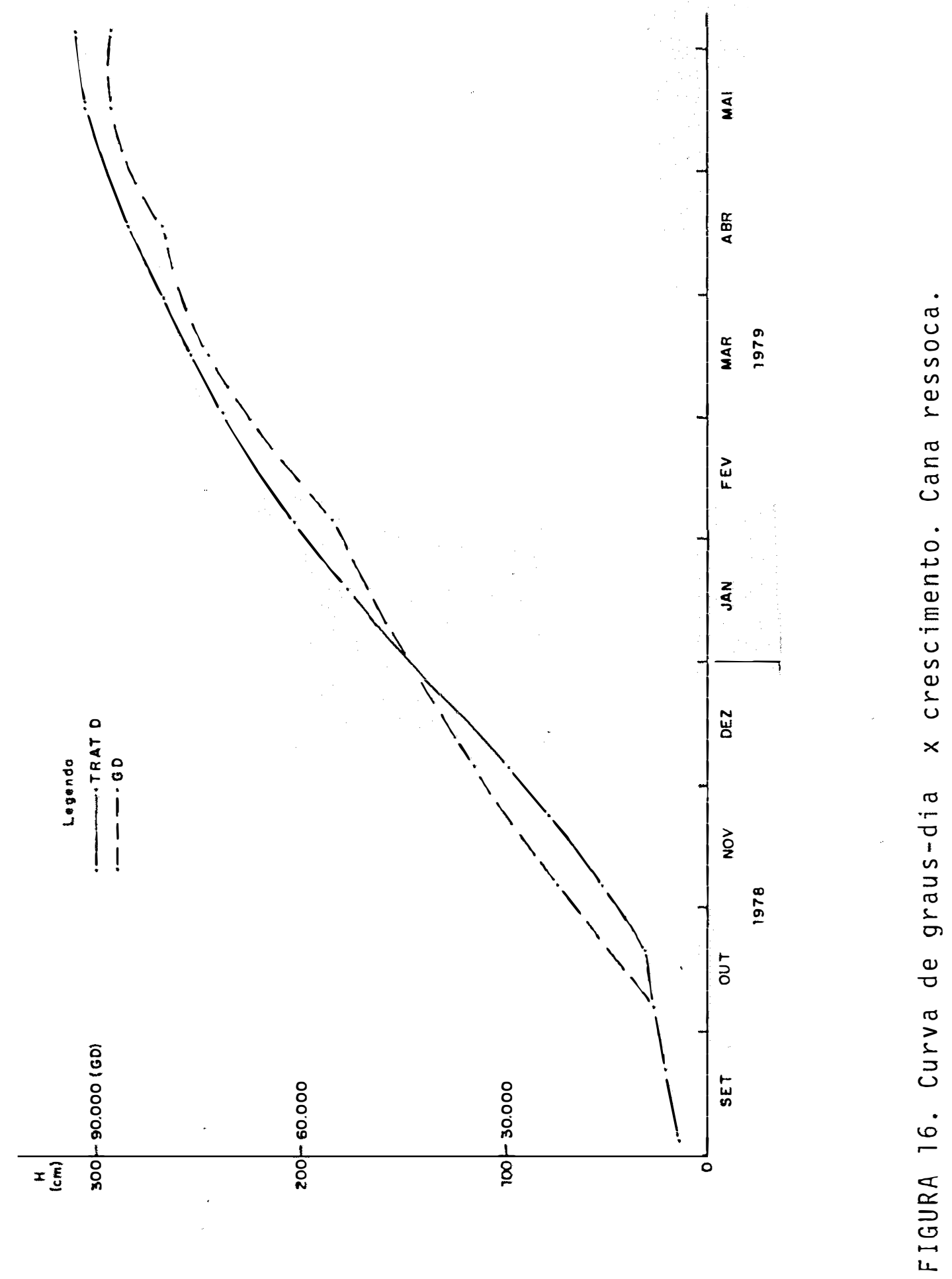


tais relações básicas de dependência clima x crescimento, possam ser utilizadas para definir condições de crescimento em situações climáticas diversas, constituindo-se em um dos elementos básicos para previsão de corte, e de rendimento agrícola.

\subsection{Produtividade}

Os dados de produtividade que se encontram na Tabela 17 foram analisados em blocos casualizados, e os resul tados estão na Tabela 18.

Como o teste $F$ para tratamentos não foi significativo ao nivel de $5 \%$ de probabilidade, isto indica que não foram detectadas diferenças entre as médias de tratamento a es se nivel de probabilidade, tanto para a socacomo para a ressoca.

Ocorréncia de precipitações elevadas no período de maior desenvolvimento vegetativo beneficiou a testemunha, tanto a cana soca como a ressoca. Apesar da não significància entre as médias de tratamento na cana soca, esta apresentou uma diferença de 19,37 ton/ha entre a testemunha e o tratamento irrigado a nível de 0,8 ECA. Na ressoca esta diferença foi muito menor, mas, a ocorrência de precipitação foi maior que no período da cana soca. DEMETRIO (1978), SOUSA (1976) e outros pesquisadores encontraram resultados mais favoráveis à irrigação. 


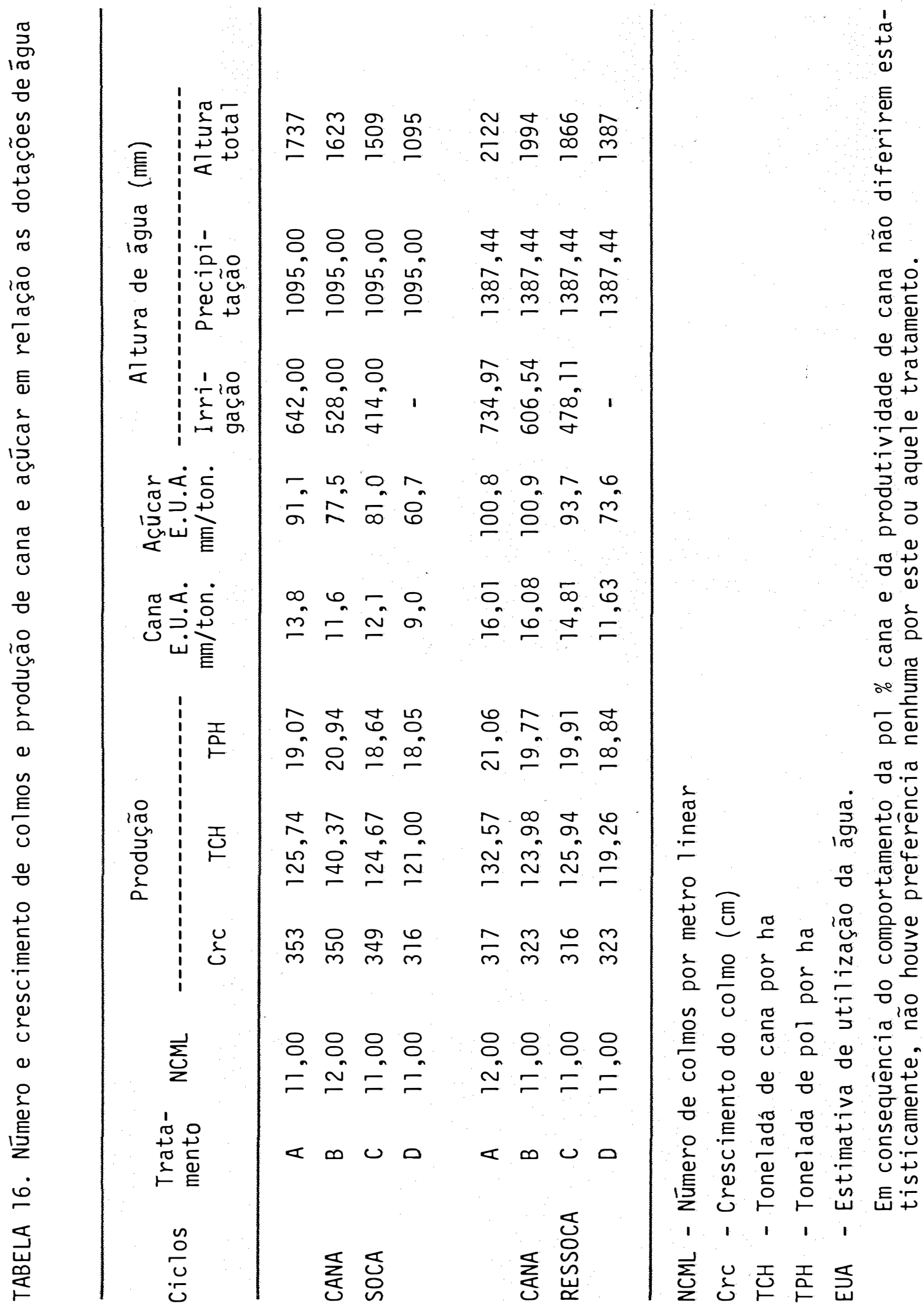




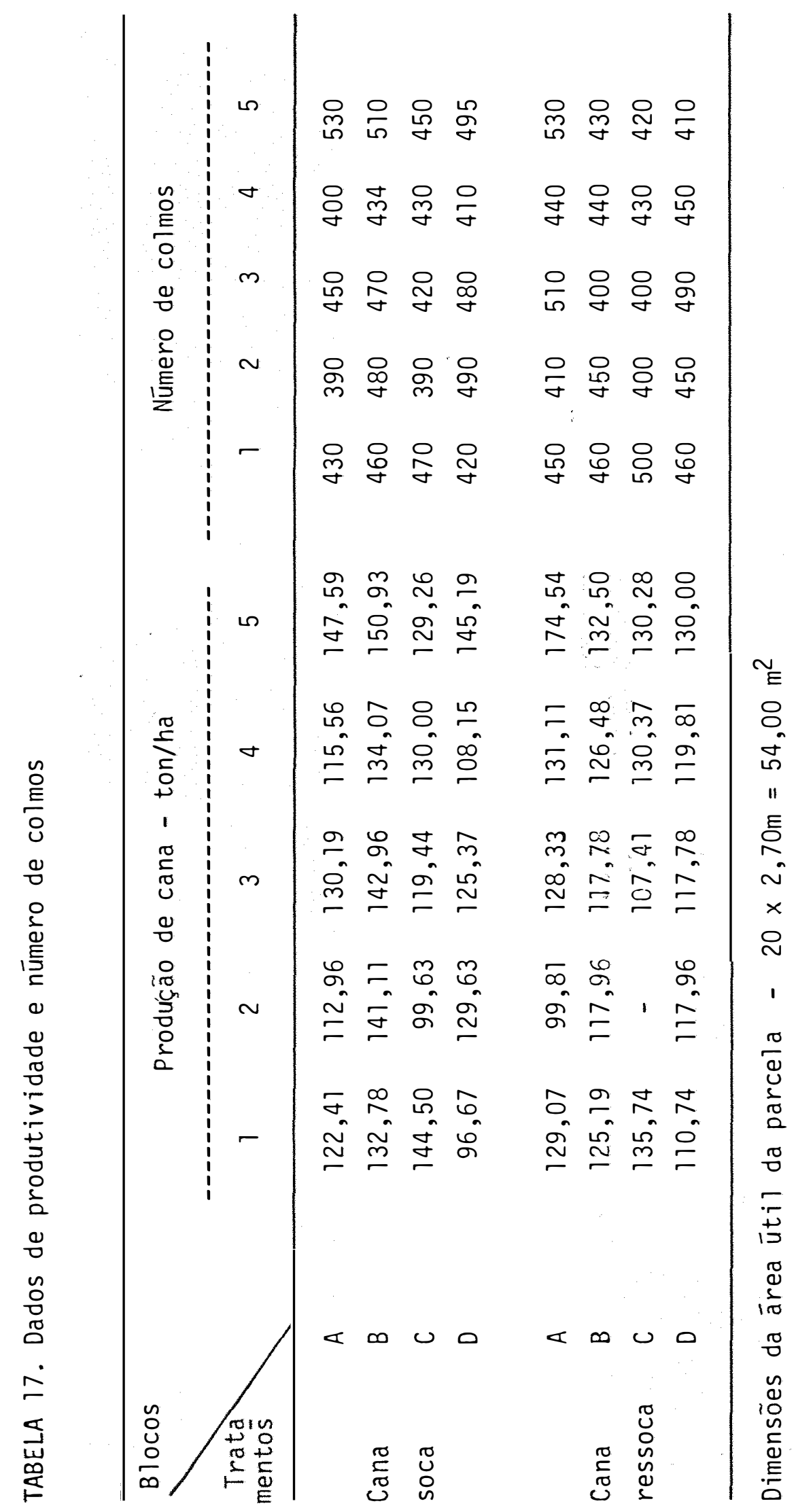




\subsection{Número de colmos}

Os dados de nūmero de colmos mostrados na Tabe 1 a 17 foram analisados em blocos casualizados e os resultados estão na Tabela 19.

Como o teste $F$ para tratamentos não foi significativo ao nível de $5 \%$ de probabilidade, isso indica que não foram detectadas diferenças entre as médias de tratamento a esse nivel de probabilidade, tanto para a soca como para a res soca.

Estes resultados tanto para soca, como ressoca estão bem próximos àqueles encontrados por DEMETRIO (1978) e SCARDUA e SOUSA (1976) nos tratamentos irrigados e maiores que os dados obtidos por SOUSA (1976a) e SOUSA (1976b).

Os resultados aqui obtidos confirmam os de cres cimento como um elemento útil para estimar a produtividade da cana-de-açūcar.

\subsection{Dotação de āgua e produtividade}

A aplicação de āgua à cultura, em função da eva poração do tanque Classe A relacionada com a produtividade, para os diversos tratamentos pode ser observada na Tabela 16.

De acordo com os dados já analisados observouse que estatisticamente não houve diferença significativa en- 
TABELA 18. Anālise de variāncia dos dados de produtividade de cana e médias de tratamentos

Cana soca

Causas de variação

G.L.

Q.M. e significāncia do teste $F$

\begin{tabular}{lrc}
\hline Tratamentos & 3 & $364.75 \mathrm{n} . \mathrm{s}$. \\
B locos & 4 & 337.84 \\
Residuo & 12 & 181,06 \\
\hline Total & 19 & - \\
\hline
\end{tabular}

Cana ressoca

Causas de variação

G.L.

Q.M. e significāncia do teste $F$

\begin{tabular}{lrc}
\hline Tratamentos & 3 & 160.71 n.s. \\
B 1ocos & 4 & 526.95 \\
Residuo & 11 & 164.30 \\
\hline Total & 18 & - \\
\hline
\end{tabular}

Média de tratamentos

Cana soca

$\overline{\mathrm{m}}_{A}=125.74$

$\overline{\mathrm{m}}_{\mathrm{B}}=140.37$

$\overline{\mathrm{m}}_{\mathrm{C}}=124.56$

$\hat{m}_{D}=121.00$

$$
\text { C.v. } \begin{aligned}
& =10,52 \\
\Delta & =25,27
\end{aligned}
$$

Média de tratamentos

Cana ressoca

$\overline{\mathrm{m}}_{A}=132.57$

$\overline{\mathrm{m}}_{\mathrm{B}}=123.98$

$\overline{\mathrm{m}}_{\mathrm{C}}=125.95$

$\bar{m}_{D}=119.26$

C.V. $=10.29 \%$

Teste de Tukey (5\%)

$$
\begin{aligned}
& \Delta_{1}=21,41 \\
& \Delta_{2}
\end{aligned}
$$


TABELA 19. Análise de variāncia dos dados de nūmero de colmos e médías de tratamentos

Cana soca

Causas de variação

G.L.

Q.M. e significāncia do teste $F$

\begin{tabular}{lrc}
\hline Tratamentos & 3 & 1561,38 n.s. \\
Blocos & 4 & 3336.54 \\
Residuo & 12 & 1037.21 \\
\hline Total & 19 & - \\
\hline
\end{tabular}

Cana ressoca

Causas de variação

G.L.

Q.M. e significāncia do teste $F$

Tratamentos

Blocos

Resĩduo

Total

Média de tratamentos

Cana soca

$\bar{m}_{A}=440.00$

$\bar{m}_{B}=470.80$

$\overline{\mathrm{m}}_{\mathrm{C}}=432.00$

$\bar{m}_{D}=459.00$

C.V. $=7.15$

$\Delta=60.49$
Média de tratamentos

Cana ressoca

$\bar{m}_{A}=468.00$

$\bar{m}_{B}=436.00$

$\bar{m}_{C}=430.00$

$\bar{m}_{D}=452.00$

C.V. $=8.88$

$\Delta=74.44$
1458.33 n.s.

857.50

1570.83 
tre as médias de tratamento, tanto para soca como para ressoca. Embora não haja diferenças significativas a Tabela 16 mos tra que a cana soca teve uma produtividade maior que a ressoca e no tratamento B da soca teve uma produtividade de 19,37 ton/ha a mais do que a testemunha, EARLY (1974) obteve 12,70 ton/ha a mais do que o tratamento não'irrigado, valor este menor do que aquele obtido na presente pesquisa.

DEMETRIO (1978), SOUSA (1976a), THOMPSON e COLLINGS (1963), FOGLIATA (1972), SOUSA (1976b), THOMPSON et a $2 i i$ (1967), BARRETO etalii (1971), e outros obtiveram aumentos de produtividade maiores, mas todos referidos a cana planta, em que, geralmente os tratamentos irrigados respondem melhor à irrigação, pois o ciclo vegetativo é mais prolongado e passa por um período de es tiagem.

0 potencial de produtividade da cana soca é me nor que da cana planta, e a ressoca por sua vez tende a produ zir menos que a soca. SCARDUA e SOUSA (1976) para uma irrigação de 0,6 ECA por gotejamento encontraram 89,40 e 83,93 ton/ ha para cana soca e ressoca respectivamente, valores estes inferiores aos da presente pesquisa. SOUSA (1976a) em irriga cão por aspersão obteve produções inferiores aos desta pesqui sa, em cana soca e ressoca.

A não significāncia da produtividade entre cana í rigada pode ser atribuĩda às altas precipitações ocorridas no perīodo de maior atividade vegetativa tanto da soca como a ressoca conforme mostra a Tabela 16, $1.095 \mathrm{~mm}$ na cana soca e $1.387 \mathrm{~mm}$ na ressoca. 
FOGLIATA (1972) na Argentina observou que não houve diferenças significativas entre tratamentos irrigados com precipitações de $620,90 \mathrm{~mm}$ e com precipitações de 1208,50 mm não houve diferença significativa entre os tratamentos ir rigados e o não irrigado, confirmando os resultados aqui obtidos.

De acordo com os experimentos impostos à cultu ra da cana, observa-se que no tratamento $B$ houve um aumento de 19,37 ton/ha a mais que a testemunha e recebera $528,00 \mathrm{~mm}$ de lāmina d'água de irrigação, que somados às precipitações resulta numa utilização de água de $11,6 \mathrm{~mm} /$ ton. Para ressoca 0 tratamento $C$ teve 6,68 ton/ha a mais que a testemunha com uma utilização de àgua de $14,81 \mathrm{~mm} /$ ton conforme Tabela 16 . A relą ção de consumo d'água por tonelada produzida para cana soca foi idéntica aquela obtida por SOUSA (1976a), mas inferior a obtida por FOGLIATA (1974), SOUSA (1976b) e superior a obtida por DEMETRIO (1978). Para ressoca a relação obtida na presente pesquisa foi superior a todas relações obtidas pelos autores ci tados.

Entre os tratamentos irrigados o consumo de água parà produção, a melhor resposta foi o tratamento $B(0,8$ ECA $)$ na soca, e tratamento C $(0,6$ ECA $)$ na ressoca. DEMETRIO (1978) obteve 0,6 ECA como o tratamento mais indicado para irrigação em escala comercial na cana planta. Deve-se ponderar que estas relações tem uma alta dependēncia das precipitações pluviomé tricas. E para a presente pesquisa conforme discutido anterior 


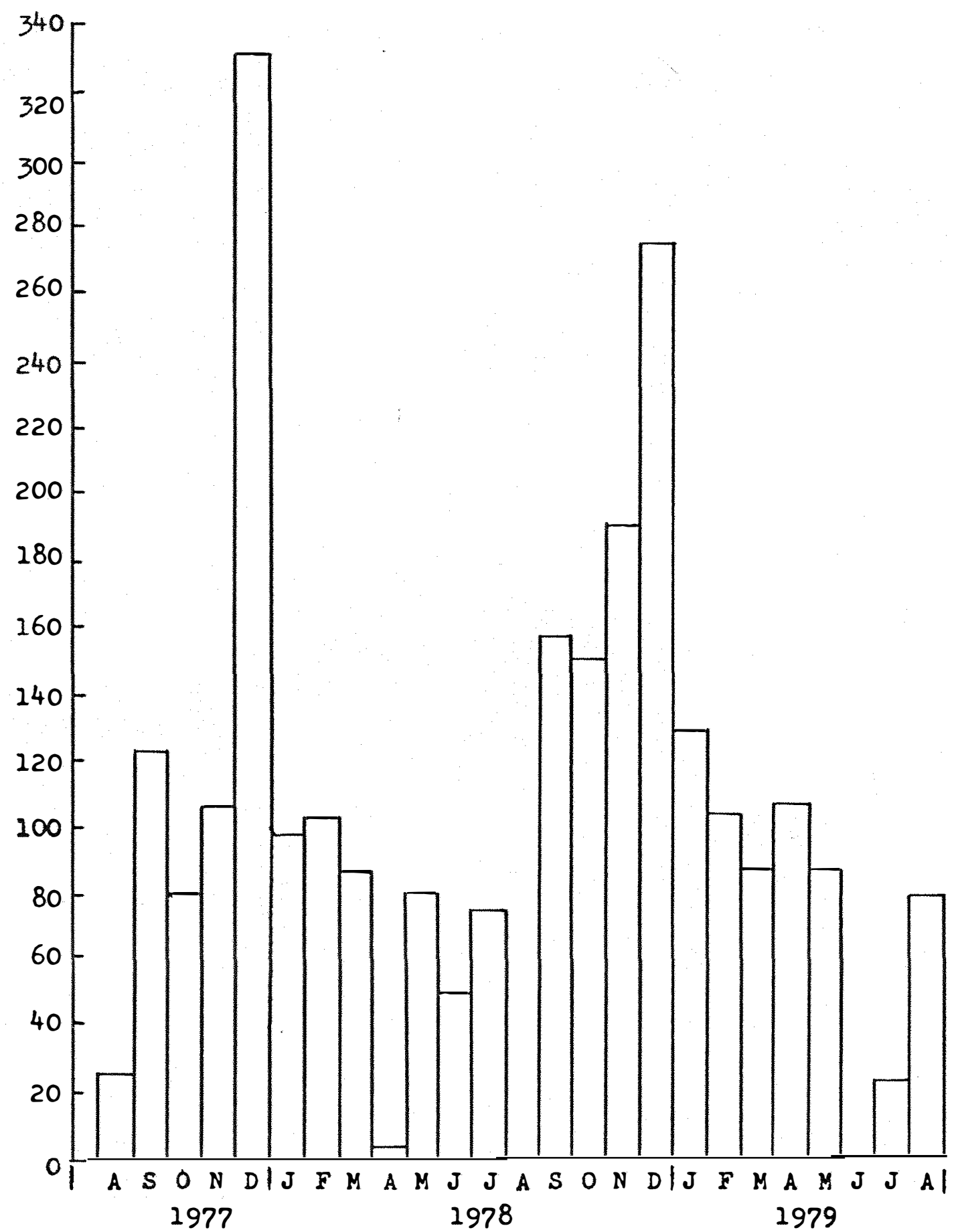

FIGURA 17 - Precipitações pluviométricas. Posto DER-ESALQ/USP 
mente, as relações consumo d'água para produção, estão elevadas quando comparadas àquelas obtidas por vārios pesquisadores, e considerando ainda o baixo aumento de produção entre os tratamentos irrigados e não irrigados, leva a conclusão que a utilização do tanque de evaporação Classe "A:" para o contro le da irrigação por gotejamento é um bom critério em regiões de condicões climáticas como as deste experimento.

Considerando-se os resultados obtidos e as anā lises estatísticas, necessārio serā o estudo econōmico para se chegar a alguma conclusão favorável ou contrāria a irrigacão por gotejamento na cana soca e ressoca, nas condições do experimento. 
80.

5. CONCLUSOES

Os dados pesquisados, analisados e discutidos neste trabalho, permitiram que se tirassem as seguintes conclusões:

1. Houve diferença de produção entre os tratamentos irrigados, o que mostra ser o tanque classe "A" um bom paràmetro para o controle da irrigacão, mas esta diferença não foi significativa estatisticamente, portanto, a irrigacão não deve ser recomendada para cana soca e ressoca nas condições de solo e clima semelhantes a da ārea experimental.

2. Nas condicões climáticas sob as quais se de senvolveram os ensaios, houve uma significativa correlação en tre o:crescimento, nos tratamentos irrigados e os valores de graus dia corrigidos acumulados, calculados para o periodo cor respondente, de acordo com a metodologia proposta $\left(G D_{T}\right)$. 
BARRETO, G.B.; R. ALVARES; S.P. B.ICUDO e H.V. ARRUDA, $197 i$. Resultados preliminares de irrigaça de cana-de-açúcar pe10 sistema de sulcos, em latossolo roxo. Bragantia, Campinas, 30(21): 277-288.

BASSINEL 0, A.I.; S. MATSUOKA; A.C. MENDES, 1976. Variedades de cana-de-acúcar para o Estado de São Paulo. Boletim Técnico do PLANALSUCAR. Araras (SP), $\underline{3}: 8-9$.

CHANG, J.H.; R.B. CAMPBELL; H.W. BRODIE E L.D. BAVER, 1967. Evapotranspiration research of the HSPA Exp. Sta. In: Congr. Int. Soc. Sug. Cane Tec., 12., Puerto Rico. Proceedings. Amsterdam, Elsevier, p. 10-14.

CAMPBELL, R.B., 1968. The economics of supplementary irrigation in sugar cane. Int. Sug. Jour. London, 70 (839): $43-45$. 
COMISSAO DE SOLOS DO SERV. NAC. DE PESQ. AGRON., 1960. Levan$\frac{\text { tamento }}{\text { 10. Rio de }} \frac{\text { reconhecimento }}{\text { Janeiro, Ministes }} \frac{\text { solos }}{\text { Jo do }} \frac{\text { Estado de Agricultura. }}{634 \mathrm{p} \text {. }} \frac{\text { São }}{\text { (Bo- }}$ letim 12).

CRUCIANI, D.E., 1972. Balanço hîdrico em solo cultivado com cana-de-açūcar: utilização do método de moderação de neutrons. B. cient. CENA. Piracicaba, nọ 008, $35 \mathrm{p}$.

DEMETRIO, C.G.B., 1977. Teste de Dunnett. Piracicaba, ESALQ / USP, 16p. (Seminário apresentado no Curso de Pós-Graduação em Experimentação e Estatística da ESALQ).

DEMETRI0, V.A., 1978. Efeito da àgua do solo e temperatura ambiente no rendimento agrícola e industrial da cana-de-açucar (Saccharum spp). Piracicaba. ESALQ/USP. 98p. (Tese de Doutoramento).

EARLY, A.C., 1974. The yield response of sugarcane to irrigation in the Phillippines. In: Congr. Int. Soc. Sug. Cane Tech., 15, Durban. Proceedings. Durban, Hayne \& Gibson, p.679-693.

EAVIS, B.W., 1972. Effects of flooding on sugarcane growth. II. Benedits during subsequent drought. In: Congr. Int. Soc. Sug. Cane Tech., 14, Louisiana. Proceedings. Louisiana, Franklin Press, p.715-721.

FAUCONNIER, R. E D. BASSEREAU, 1970. La canne a sucre. Paris, Ed. Maisonneuve e Larose. $468 \mathrm{p}$.

FOGLIATA, F.A., 1972. Influēncia de diferentes niveles de humedad disponible sobre el crescimiento y producción de la caña de azucar. Rev. Ind. y Agricola de Tucumān. Argentina $\underline{49}(1): 39-56$. 
FOGLIATA, F.A., 1974. Sugarcane irrigation in Tucumān. In: Congr. Int. Soc. Sug. Cane Tech., 35, Durban. Proceedings. Durban, Heyne \& Gibson, p.665-667.

FRITSCHEN, I.J. e R.H. SHAW, 1961. Evapotranspiration for corn as related to pan evaporation. Agron. J., 53: 149-150.

GOLDBERG, S.D.; B. GORNAT e D. RIMON, 1976. Drip irrigation: principles, design and agricultura pratices. D.I.S. Publications, israel.

GOLDBERG, S.D. e M. SHMUELI, 1971. The effect of distance from the tricklers on soil salinity and growth and yield as sweet corn in an Arid. Zone. Hort. Science. 6: 6 .

HALEVY, L.; M. BOAZ; Y. ZOAR; M. SHANI e H. DAN, 1972. Trickle irrigation. FAO. Fifth session on the working party on water resources and irrigation. Bucarest, Romania.

HARDY, M., 1966. Water consumptive of sugarcane plant. Mauritius Sug. Ind. Res. Inst. Ann. Reptr., p.95-101.

HUMBERT, R.P., 1968. Irrigation of sugar cane. In: _. The growing of sugar cane. Amsterdam, Elsevier, p.370-372.

INFORZATO, R.; ALVARES, R., 1957. Distribuição do sistema radicular da cana-de-açúcar em solo tip̀o terra-roxa legitima. Bragantia 16: 1-3.

ISRAELSEN, 0.W. e HANSEN, V.E., 1965. Princípios y aplicaciones del riego. 3ạ ed. Barcelona, Ed. Revertē, $396 \mathrm{p}$.

ISRAELSEN, 0.W., 1963. Principios y practicas del riego. Barcelona. Ed. Reverté, $345 p$. 
84.

ISOBE, M., 1969. Water utilization. II. Yield-water relations hip. In: Congr. Int. Soc. Cane Tech., 13., Taiwan. Proceedings. Amsterdam, Elsevier. p. 49-54.

JAIME, J.R.R., 1973. Riego por goteo del Chile Caribe en el

Distrito de Riego del Rio Yaqui. Memorandum Técnico no 320 da Secretaria de Recursos Hidräulicos. Sonora, México D.F. $63 \mathrm{p}$.

KENWORTHY, A.L., 1972. Trickle irrigation, the concept and guidelines for used. Research Report 165. Michigan State University, Michign.

KRUTMAN, S., 1962. Do crescimento da cana sob condicões natú rais. Bol. Técnico Int. Agron. Nord. Recife, 17: 4-28.

KRUTMAN, S., 1963. Método para indicação de regas: evapotrans piração da cana e evaporação. Bol. Téc. Inst. Agron. Nord. Recife, 22: $1-18$.

LANE, J.H. e L. EYNON, 1934. Determination of reduzing sugar by fehling's solution with methylene blue indication. London Norman Rodgerk. $8 \mathrm{p}$.

MANIERo, M.A., 1980. Aplicação do Método de Graus Dia em cana-de-açúcar (Saccharum spp.). Piracicaba. ESALQ/USP. 76 p. (Dissertação de Mestrado)

MENEZES, F.A. da F., 1982. A politicica do açūcar. Revista SAC CHARUM, Piracicaba, 5(19): $28-29$.

MONGELARD, J.C. e L.G. NICKEL, 1972. The sugarcane plant in the soil-plant-atmosphere continuum. In: Congr. Int. Soc. Sug. Cane Tech., 14, Louisiana. Proceedings. Louisiana, Franklin Press, p. 827-40. 
MORAES REGO, L.F.M., 1932. Notas sobre a geomorfologia de São Paulo e sua génesis. Inst. Austr. Geogr. de São Paulo. São Paulo. São Paulo Editora Ltda.

RANZANI, G; 0. FREIRE e T. KINJ0, 1966. Carta de solos do Municipio de Piracicaba. Centro de Estudos de Solos. Piracicaba, ESALQ/USP. 85p.

RANZANI, G., 1976. Subsidios à geografia de Piracicaba. Instituto Histō rico e Geográfico de Piracicaba/SP. Editora Franciscana. 79p.

RICHARDS, L.A., 1947. Pressure-membrane apparatus, construction and use. Agr. Eng., 28: 451-454.

ROBINSON, F.E.; R.B. CAMPBELL e J.H. CHANG, 1963. Assessing the Utility of Pan Evaporation for Controlling Irrigation of Sugar Cane in Hawaii. Agr. Jour. Madson 55: 444-46.

ROBINSON, F.E., 1963. Soil moisture tension, sugarcane stalk elongation and irrigation interval control. Agron. J. 55(5): 481-483.

SCARDUA, R. eJ.A. e J.A.G.C., SOUSA, 1976. Comportamento da cultura da cana-de-açūcar irrigada por gotejamento. Brasil Açucareiro, Rio de Janeiro, 87(3): 57-69.

SATTERTHWAITE, F.E., 1946. An aproximate distribution of esti mates of variance components. Biometrics. 2: 110-114.

SETZER, J., 1946. Contribuição para o estudo do clima do Eśtá do de São Paulo. D.E.R. São Paulo IX a XI: 1-237 (separata).

SOUSA, J.A.D.C., 1976a. Estudo do consumo de água pela cultura da cana-de-açūcar (Saccharum spp.). Piracicaba, ESALQ/ USP. 82p. (Dissertação de Mestrado). 
SOUSA, J.A.G.C., 1976b. Estudo da tensão da āgua do solo na cultura da cana-de-açūcar (Saccharum spp.). Limeira, Facul dade de Engenharia de Limeira, da Universidade Estadual de Campinas, 163p. (Tese de Doutoramento).

THOMPSON, G.D. e D.F. COLLINGS, 1963. Supplementary irrigation. Bul1. S. Afr. Sug. Assoc. Exp. Sta., Mount Edgecombe, (17).

THOMPSON, G.D., 1967. The relationship of potential evapotrans piration of sugarcane environment factors. In: Congr. Int. Congr. Int. Soc. Sug. Cane Tech., 12., Puerto Rico. Proceed ing. Amsterdam, Elsevier, p.3-9.

THOMPSON, G.D.; J.M. GOSNELL e P.J.M. de ROBILLARD, 1967. Res posses of sugarcane to supplementary irrigation in two soils in Natal. Expl. Agric. 3: 1-16.

TULER, V.V.; A.E. NASCIF; D. de SOUZA; H.J. AZEVEDO e A.C. SA LIBE, 1981. Irrigação por gotejamento da cana-de-açūcar com diferentes niveis de āgua. In: 20 Congresso Nacional da PLANALSUCAR/STAB, Brasil.

VILLA NOVA, N.A.; A.R. PEREIRA e M.J. PEDRO Jr., 1972. Estima tiva de graus-dia acumulados acima de qualquer temperatura base, em função das temperaturas māximas e mỉnimas. Caderno de Ciéncias da Terra no 30, Instituto de Geografia USP. 